\title{
MARGRIET GOSKER
}

ORCID: 0000-0002-2104-6804

\section{ANNA MARIA VAN SCHURMAN (1607-1678). A LEARNED MAID AND HER QUEST FOR AUTHENTIC SPIRITUALITY ${ }^{1}$}

DOI: $10.15290 /$ sp.2020.28.01

\begin{abstract}
I investigate Van Schurman's spiritual and scientific life by studying her biography. What is the balance between both? Her Christian faith tried to understand intellectually the essence of Christian truth. Contemporaries complained that she was quite a different person

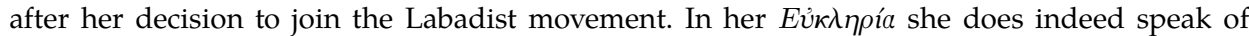
her 'change'. She renounced the importance of her former scientific activities and stressed the need for a pious life in Christ. But was it really such a radical break? This article will show a lot of continuity both in her life and in her work.
\end{abstract}

Key words: Anna Maria Van Schurman, spirituality, scientific life, biography

Abstrakt. Artykuł opisuje życie duchowe i działalność naukową Anny Marii van Schurman poprzez pryzmat jej biografii. W jaki sposób uczona godziła ze sobą religię i naukę? Esencję prawdy chrześcijańskiej pragnęła poznać poprzez połączenie myśli naukowej i wiary. Ówcześnie komentowano, że po wstąpieniu do sekty Labadystów, jej osobowość uległa drasty-

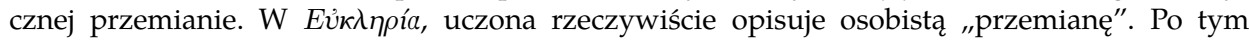
wydarzeniu uznała swą dotychczasową działalność naukową za nieważną, podkreślając konieczność cnotliwego życia w Chrystusie. Czy jednak ta zmiana rzeczywiście była prawdziwie fundamentalna? Autorka artykułu podkreśla trwałe elementy w życiu i dorobku uczonej.

Słowa kluczowe: Anna Maria van Schurman, duchowość, życie naukowe, biografia

\section{Introduction}

Anna Maria van Schurman is one of the most interesting figures in Dutch history ${ }^{2}$. She was brilliant in many ways. She was active as an artist, she

1 I thank Rev. Harvey Richardson, Methodist minister in Britain, for correcting my English.

2 Van Schurman, also written as Schuurman, Van Schuurman, Scheurman, van Scheurmann, Schuurmans, van Schuurmans, Schuermans, van Schuerman, Schurman, von Scurman, Schotel, Aanteekeningen, 2. His book counts 265 pages and then starts a new numbering for the Aanteekeningen (Annotations, Appendices and Supplements). 
could model and cut-out paper, she wrote poems, she made drawings, embroidery and woodcarving. She practised calligraphy and collected insects. She made many portraits and self-portraits. She was mainly self-taught, but Magdalena van de Passe, daughter of Crispijn van de Passe, a well-known engraver in Utrecht, possibly taught her the art of engraving ${ }^{3}$. Probably they knew each other from Cologne, the place where they were both born. In 1643 Van Schurman became a member of the Sint-Lucasgilde in Utrecht ${ }^{4}$. She is mentioned by Van Houbraken in his famous book on Dutch painters as an expert in philosophy and in the knowledge of the Bible ${ }^{5}$. She was a respected theologian and philosopher indeed, and also a fine musician. Not only her theological work, but also her artistic activities became instruments of praise to the Lord. She was both pious and intelligent, always trying to understand intellectually the things she believed deep inside. She wanted to express her faith not only in an intellectual way, but also in all the varied aspects of her life. This is why she adopted Pietism and embraced the spirit of the Calvinistic Nadere Reformatie. Both are variants of the English and Scottish religious movements of Puritanism which sought to 'purify' the Anglican Church ${ }^{6}$. In her sixties her criticism of the Reformed Church, with its nominal Christianity and its lack of spiritual devotion, became stronger. Finally she left the Reformed Church and decided to join the Labadist movement. Here again she embraced the idea of the purification of the Church, because her longing for the original sharing of love among the first Christians, as described in the Bible (Acts 2), was more vivid than ever. Because of her versatility and her various interests and knowledge, the Van Schurman investigation is immense and diverse.

I will not focus on her musical, poetic or artistic qualities, or on her philosophical activities ${ }^{7}$. An overview of the reception history of Anna Maria van Schurman since the $17^{\text {th }}$ century is already published ${ }^{8}$. Recent substantial studies of her essay (Dissertatio) about the capability of women for scientific

3 Van Beek 2007², 19. Not Margaretha, Van der Stighelen 1986, Spaens loot, 27.

4 A guild of artists and makers of artistic handycraft, Van der Stighelen 1992, 65. Douma 1924, 9. Van der Puyl 1806, 14.

5 "en 't pit en merg der Filosofy en Bybelschriften bevatte, en daar over met de geleerde Mannen van hare eeuw brieven wisselde", Van Houbraken, I, 1718, 315.

6 Vekeman, https://www.dbnl.org/tekst/_ons003198201_01/_ons003198201_01_0159.php?q= schurman\#hl2,30-12-2019, 706-716.

7 Van der Stighelen 1987; Verhave, Verhave 2017, 153-164; Van der Stighelen 1986, Kalligrafe, 61-82; Roothaan, Van Eck 1990, 194-211; Menagius 1690.

8 De Baar, Rang 1992, Minerva of Savante, 9-28. 
studies are also provided ${ }^{9}$. I will investigate particularly her theological and spiritual life by studying her biography, where both elements are present. Most of it we know from her theological contributions and her numerous letters and poems, published in different places or preserved in archives. Some of her letters are published in her Opuscula ${ }^{10}$. Her correspondence is far from completely preserved. Many of her letters remained unpublished for a long time or got lost ${ }^{11}$. Six years before her death she must have burnt all the letters which were still in her possession ${ }^{12}$. In the series Schurmanniana Pieta van Beek recently published two of her unpublished letters and also described her till 2014 unknown anthology (Florilegium, ca 1625), with statements 'on God'13. Here is still much work, waiting for future research.

Important for our present investigation are the two parts of her autobiography ${ }^{14}$. Do women have to deliver their own history to ensure they

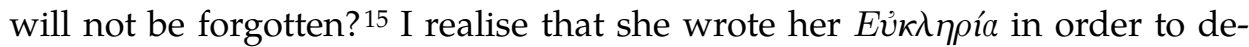
fend her transition to the Labadists, and I can imagine how this might have coloured her memory. Memories can be misleading. I noticed that she pro-

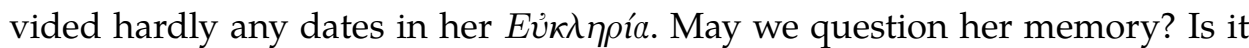

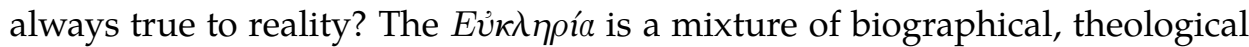
and philosophical content. We hear about her childhood and the beginning of her devotedness (Godzaligheit). She was interested in many branches of science. She loved the knowledge of grammar and languages, while she had the idea she should be an all-round student of everything ${ }^{16}$.

9 Van Schurman/Spang, 2009; Usakiewicz, Problem, 2019, 17-38; Van Eck 1992, 49-60; Korczak-Siedlecka, 2016, 19-24. I thank Piotr Oczko.

10 See for her Greek letters: Van Beek 2018. In 1825 three of her Hebrew letters are published, in: Bikure Ha-Itim, Goldman 1999, 167. Maas wondered if her letters to women were seen as less interesting than her letters to man? (Maas 2016, 14).

11 Van Beek http://annamariavanschurman.org/publications/publications-by-anna-mariavan-schurman/, 27-01-2020. I will not provide information on all prints, translations and reprints of her work. For an (incomplete) list of her until then unpublished work see Douma 1924, Appendix D, 76-84, Appendix E, 85-86, Appendix F, 87-88.

12 Schotel 1853, 131.

13 Van Beek 2014, Uw lieftallige brief; Van Beek 2015, Verslonden; Van Beek 2014, On God.

14 There is some discussion whether or not Van Schurman is the author of the Continuatio.

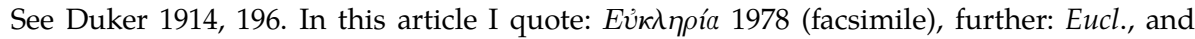

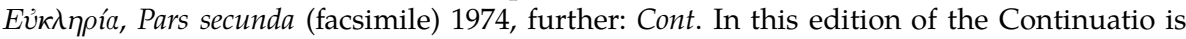
included: Kort verhaal van eenige dingen, raakende de vermaarde perzoon van Juffr. Anna Maria van Schuurman, 73-92.

15 Meyer, s.d., http://frauen-und-reformation.de/?s=bio\&id=61, 30-12-2019.

16 She wanted to know 'alles wat weetlijk is', Eucl., 44-45. 
In her glorious period she had many international connections with royalty. The Polish queen Maria Louisa Gonzaga visited her in $1645^{17}$, and she welcomed the Swedish Lutheran Queen Christina in $1654^{18}$. She had the world at her feet ${ }^{19}$. She had numerous contacts with scholars, politicians, scientists and clergy all over Europe, not only Reformed, but also 'Ecumenical'. One of her texts can be easily interpreted ecumenically: "With all true Christians, in what places they are scattered or in what gatherings they may meet, I remain united with them in our head Christ and his Spirit" ${ }^{20}$. But for Van Schurman not all Christians are 'true' Christians. She still was aware of the essential unity of the Church, and defended herself against the accusation of being a schismatic, but we cannot say she was 'ecumenically' involved ${ }^{21}$. That would be a little unhistorical. But we do know she was in contact with bishop Meletios Pantogalus of the Greek Orthodox Church of Ephesus ${ }^{22}$. She corresponded with Roman Catholics such as Cardinal de Richelieu ${ }^{23}$ and Professor Pierre Gassendi (Paris) ${ }^{24}$, with Presbyterians like Samuel Rutherford (St Andrews, Scotland) ${ }^{25}$ and with Anglicans such as Samuel Collins (Cambridge ${ }^{26}$. She had a large network of 'ecumenical' contacts and we find her inscription in many Alba Amicorum ${ }^{27}$.

For her Album pages she often used calligraphy in Hebrew or other ancient oriental languages, as we can see in the - rather impersonal - inscription in the Album of Johannes Albertus Zaunschliffer (1655), showing only her symbolon, her signature and the Hebrew text of Psalm 16:3. , translated: 'As for the saints in the land, they are the noble, in whom is all my delight' 28 . She even wrote

\footnotetext{
17 Van Beek 2007², 192.

18 Van Beek 2007², 156. Van Beek 2012, Habent sua fata libelli, 199-209.

19 Brouwer 2008, 37.

20 Eucl., 152.

21 The idea is defended, that the 'Nadere Reformatie' (Witsius, Teellinck) are reformed with an ecumenical touch, De Reuver 2019, 663.

22 Opuscula 1648, 161-162.

23 Schotel 1853, 121; Veth 1922, 229.

24 Opuscula 1648, 212-214.

25 Van Beek 2007², 218.

26 Van Beek 2007², 166.

27 We find her inscription in the Alba of Jacobus Alting, Charles de Montigny de Glarges, Johannes Fredericus Gronovius, Jacobus Heyblocq and Abraham de Zadeler (kept by the Koninklijke Bibliotheek in Den Haag), Van Beek 2007², 251.

28 Van Beek 1992, Verbastert, 24. The Reformed Minister Joh. Albertus Zaunschliffer (16341678) was one of my predecessors in Oostzaan. His Album Amicorum is in the University
} 
her name in Hebrew, for example in the Album of Godefridus Junckerus (Dantzig) ${ }^{29}$. Her own Album (1638) was still in existence in 1853, but is now unfortunately $\operatorname{lost}^{30}$. The only known female Album to which she contributed was that of Johanna Koerten-Blok ${ }^{31}$. Recently I discovered her inscription in the Album of Johann Ernst Gerhard (in the private collection of the late Mr M. Hertzberger ${ }^{32}$, which also includes an inscription of Menasseh ben Israel ${ }^{33}$. This inscription of Van Schurman has never been published before.

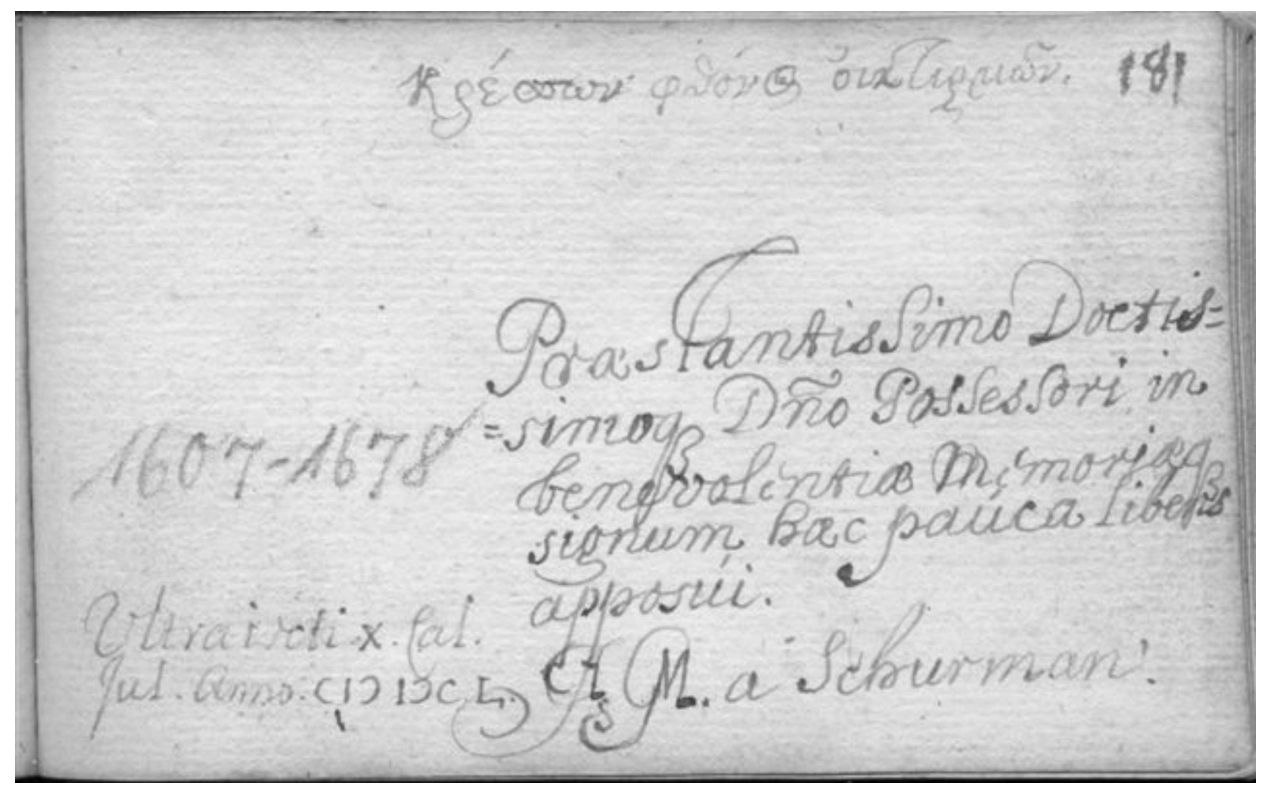

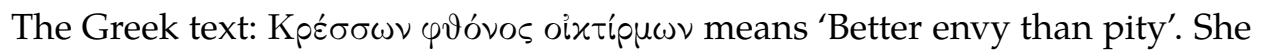
wishes the owner of the Album success in all his learned activities. It would be better if he would arouse jealousy by his excellent work, than if he would earn compassion resulting from his botched work. Envy can produce a type of rivalry which may have positive effects. People in a stronger position have

Library in Amsterdam [Ms XXV C 27], Postma,Verheij 2009, 43; Postma 2003, 209; Rappard 1856, 123.

29 Van Beek 2014, Het is dezelfde geest, 53.

30 It was in the possesion of the collector G.J. Beeldsnijder van Voshol (†18 April 1853). See Schotel 1853, Aanteekeningen, 30.

31 Van Beek 2007², 151.

32 I thank Ferenc Postma for his help and Dr. D. Hertzberger for his kind admission to publish it.

33 Postma, Verheij 2009, 39-40. 
pity over those in a weaker position. Therefore it is better to be envied than pitied. The text comes from Pindarus and is also known from Herodotus ${ }^{34}$. But it was also a Dutch Proverb in the $17^{\text {th }}$ Century ${ }^{35}$, used by Vondel, Cats and Huygens: Als God behagt, beter benyd als beklagt.

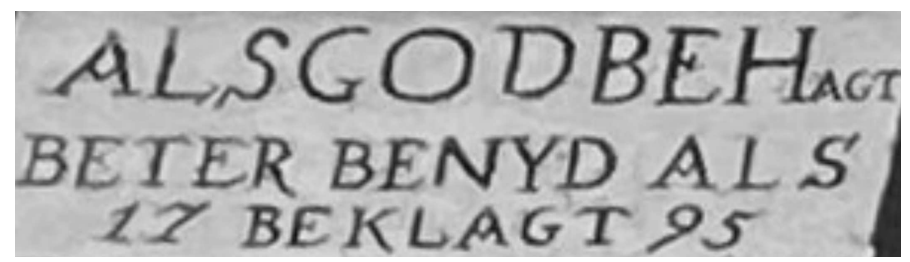

Facing Brick 1795

The Latin text in the Album:

\author{
Praestantissimo Doctis- \\ simoque Dno Possessori in \\ benevolentiae memoriaeque \\ signum haec pauca libens \\ apposui.
}

\title{
Ultraiecti X Cal. Jul. Anno MDCL. A.M. a Schurman
}

My translation: For the most excellent learned mister owner, as a sign of benevolence and remembrance I have added this little (text) with delight, Utrecht, 22 June 1650. A.M. a Schurman. Unfortunately somebody wrote Van Schurman's dates with a pencil on this page.

Van Schurman was praised as the 'Star of Utrecht', 'Minerva', 'European Pallas', 'Second Hippia', the 'Tenth Muse', 'Virginum eruditarum decus', 'Showpiece of Europe', the 'Miracle of her age', etc., as we learn from her biographers ${ }^{36}$. The Polish nobleman Hieronim Gratus Moskorzowski called her 'Ocellus' (jewel) in his Diarius rerum notabilium ${ }^{37}$. Did she enjoy it? Probably, but she also denied it. She wrote to Johan van Beverwijck in 1642, declaring that she never sought fame, neither did she deserve it ${ }^{38}$. She wrote in

34 Pindarus, Pyth, I, 85. https://sententiaeantiquae.com/2017/09/10/envy-and-pity-proverbial -wisdom/, 10-03-20. I thank Pieta van Beek for her kind advice.

35 https://www.dbnl.org/tekst/stoe002nede01_01/stoe002nede01_01_0205.php, 15-04-20.

36 Jacob 1646; Mollerus 1744, 52; Schotel 1853, 20; Birch 1909, 8; Douma 1924, 58; Van Beek 2007², 155; Larsen 2016.

37 Usakiewicz, Ocellus, 2019, 171.

38 Van Beverwijck 1672, Aenhangsel, 199. 


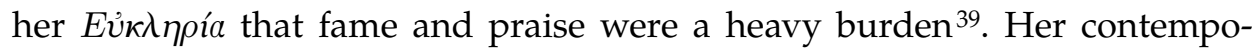
rary younger friend and biographer, the Labadist Pierre Yvon confirmed this view and stressed her reluctance to seek fame: she did not like her fame (naamruchtigheid), because of her innate modesty ${ }^{40}$.

As a child Van Schurman developed herself in many ways, as a young woman she was famous, because of her intellectual and artistic qualities. In her sixties she abandoned the Reformed Church by following the enthusiastic preacher Jean de Labadie. She was impressed by his spirituality and capabilities, and decided to join his movement. She renounced her earlier work, and broke off her academic ties. Her royal friends and academic connections no longer seemed important to her. After this religious change her scientific reputation also changed. Her former admirers could not understand her choice. They were very critical now, assuming she had lost her mind.

I will follow now her biography and pay attention to the importance of her spiritual and theological development, her pious education, her mystical experience, her love for Christ, her longing to martyrdom, her promise of celibacy, her studies on the Biblical languages, and her theological education. She developed theological views mainly about Divine Providence, Predestination, Healing, the boundary between life and death, Baptism for the dead, the Ten Commandments (especially the fourth on the Sabbath), the Holy Spirit, and Chiliasm. And she wrote didactic poems on the first three chapters of Genesis, on the decline of the Reformed Church, against worldly companionship, on the coming of the Kingdom of God in Christ, and on the Spiritual Marriage between Christ and the believing souls.

\section{Religious refugee - mystical experience - loving Christ}

As a little girl Anna Maria van Schurman was a religious refugee, like her parents and grandparents, living in stormy times. Both her parents, Frederik van Schurman (1564-1623) and Eva von Harff de Dreiborn (†1637), were of Protestant ancestry. The Van Schurmans were a well to do, noble and pious family, coming originally from Antwerp. Her grandfather Frederik van Schur-

39 Eucl., 37-29, 42, 279, 342; De Baar, Rang 1992, Minerva of Savante, 15; De Baar 1992, Eergeruchtje, 104.

40 Oprecht verhaal (Yvon) 1754, 121-122; Eucl., 24-30, 36-39, 43-48, 60-78. 
man $(† 1593)^{41}$ and his wife Clara van Lemens or Lemans (†1608) - a member of the House of Lumey from the Brabant Nobility ${ }^{42}$ - were forced to leave Antwerp as fugitives during the reign of terror of Alva, the grand duke of Toledo (1507-1582) ${ }^{43}$. The Iron Duke instituted in 1567 the Council of Troubles (Raad van Beroerten) in order to punish the iconoclasts of 1566. Did the Van Schurmans flee during the same night that Christoffel Fabricius (a former Carmelite priest, who converted to the Reformation) was burnt as a martyr, or is that a legend? ${ }^{44}$ After leaving Antwerp, the family travelled around (Hamburg, Bremen, Frankfurt am Main), and finally settled in Cologne in $1593^{45}$.

Her grandparents on her mother's side, Lucia Schlaun (1564-tunknown) and Gottschalk von Harff $(+1588)$ were noble and pious people too. Gottschalk converted to the Reformation under the influence of Lucia, who was a follower of Martin Bucer ${ }^{46}$. They too were persecuted because of their faith. As a result they had to leave Nuits (today Neuss) and settled in Cologne in $1586^{47}$. The atmosphere there was relatively tolerant at that time. Like the Van Schurmans also the Von Harffs joined the Reformed Community under the Cross ${ }^{48}$. Their daughter Eva von Harff married Frederik van Schurman on 5 November 1602. Did they live at the 'Krummer Büchel' in the house Cro-

41 According to Schotel he died in 1593 and in 1599, Schotel 1853, 3, Aanteekeningen, 47. Van der Stighelen and others give 1599, Van der Stighelen 1986, Spaens loot, 29. But presumably 1593 is the correct date. His widow occurs in a church document of 21 August 1599, proclaiming the wedding of their daughter Maria with Dirck Alewijn. Could this explain the mistake? Goebel says he came to Cologne in 1593 and died in the same year, Goebel $1852,275$.

42 Cont., 74. Larsen 2016, 34.

43 It is a misunderstanding, that her father (born $22^{\text {th }}$ October 1564) or even both her parents fled from Antwerp to Cologne, Van Lieburg, 1993, 55. Douma 1924, 8. Birch says correctly that the grandparents fled Antwerp. Birch 1909, 12.

44 Cont., 73. Was 1567 the year of their departure? Van Beek, 2014, Het is dezelfde geest, 47. Did they leave Antwerp after the beheading of Egmond and Hoorne (5 June 1568)?, Schotel 1853, 3. Larsen quotes Yvon saying it was 1568, Larsen 2016, 34. But if they fled in the same night that Christoffel Fabricius died, it should have been 4 October 1564, Marnef 1996, 124. Van der Lem https://dutchrevolt.leiden.edu/dutch/personen/F/Pages/fabritius.aspx), 2701-20. I noticed a lot of inaccuracies and contradictions in the Van Schurman investigation. Further investigation is needed, to get a more accurate picture of her life and work. Their son Abraham (1566-1573) died in Bremen, if the Van Schurman Family Bible, now in the Museum Martena in Franeker, is correct.

46 Goebel 1852, 275.

47 Van Schurman/Spang 2009, VII.

48 In 1536 and 1542-1546 Protestantism was introduced there by Hermann von Wied. Frederik and Eva were participants in this 'clandestine' Reformed Community under the Cross. They met there each day, Schotel 1853, 3-4. Goebel 1852, 41-46. 
nenberg? ${ }^{49}$ They thanked God for the birth of their three sons and one girl ${ }^{50}$. Were they all baptised in this hidden Reformed Community? ${ }^{51}$ We do not know who baptised them, but we do know that the Van Schurmans were true believers and adherents of the Reformation. They gave their children a pious Christian education. For them not only going to church, praying and reading the Bible was important, but also purity and daily practical Christian living. However, times were changing.

A heavy religious oppression against Protestants now began also in Cologne, so the family had to leave (about 1610) for their own safety ${ }^{52}$. From now on they lived in Dreiborn (or Drimborn) in the Gulik region (near Schleiden), where the Von Harffs owned a small castle. Anna Maria could read the Lutheran Bible already at the age of three. She had a sensitive spiritual nature. She experienced her first Christian mystical feelings at the age of four, and she kept having them from time to time. Sometimes she felt little sparks of Godvrugtigheit (devotion), another time it broke out into flames ${ }^{53}$. From the very beginning she must have had a strong connection to Jesus Christ. The seeds of her later Christology were already present here. Christ was central in her theology as Redeemer, Saviour, Mediator, Conciliator and Head of his Church.

The story is well-known: one day she went out with the housemaid, and while both were sitting near a beach, the maid asked Anna Maria to give her the answer to the first question of the Heidelberg Catechism. Anna Maria knew the text by heart and said fluently: 'that I am not my own, but belong with body and soul, both in life and in death, to my faithful Saviour Jesus Christ'. At the same time she experienced an overwhelming joy and an intimate deep love for Christ, an experience she would never forget ${ }^{54}$. From the very beginning Christ was central in her life.

49 Van Beek $2007^{2}$, 14. A sculpture of Anna Maria is present on the Tower Wall of the City Hall and there is also in Cologne a street named to her, but this street is elsewhere in the city. This happened thanks to the 'Kölner Frauen Geschichtsverein', Signon, Schmidt 2006, 77. Hendrik-Frederik (ca. 1603-1632), Johan Godschalk (ca. 1605-1664), Anna Maria (16071678) and Willem (ca. 1610-1615).

51 Van Beek 2014, Het is dezelfde geest, 47.

52 Goebel 1852, 42. The Reformed could not gather anymore in Cologne. They were forced to have their protestant services in Mülheim. The story is known, that on Sunday 24 April 1611 fourteen students were arrested because they had visited a Lutheran sermon, Prößdorf 2002, 33. In 1802 the prohibition of gathering was removed, Prößdorf 2002, 41-43. Blaukopp (plural Blauköpp) is a nickname for Protestants.

53 Eucl., 17.

54 Eucl., 18. 
We know that she loved De Imitatione Christi, attributed to Thomas à Kempis, describing how to follow Christ in one's personal life ${ }^{55}$. It is still one of the most widely read books of Christianity, translated in many languages and with numerous reprints. We also know that Van Schurman made plans to rewrite this 'precious booklet' in a better way ${ }^{56}$. But she never did so, because in the end - in her opinion - the lives of true living Christians showed the best way to reflect the life of Christ.

\section{Pious education - Divine providence - Predestination}

Between 1613 and 1615 the family came over to the 'Republic of the United Provinces', and settled in Utrecht, where they rented a house. As a girl of seven (or eight) Anna Maria attended the French school for two months only ${ }^{57}$. Her parents wanted to protect her, and kept her away from the roughness of the other children. A house master taught her and her brothers writing, singing, arithmetic, music, and so on. Anna Maria played both the lute and the clavichord. Frederik van Schurman taught his sons Latin, which was only reserved for boys in those days. But Anna Maria was clever and curious enough to learn without effort, so she picked up whatever she could. When she was eleven years old her father discovered her special linguistic talents. He permitted her to learn classic languages and to read classic authors, but with the condition, that she should only read books which followed the demands of serious Christian morals. Did she obey? János Nagyillés discovered some little transgression ${ }^{58}$. Her wish to learn languages - especially Latin - was so strong, that her father's allowance seemed to her a 'divine providence' 59 . She was always convinced of God's providence, both in her personal life and in her theology. We will see

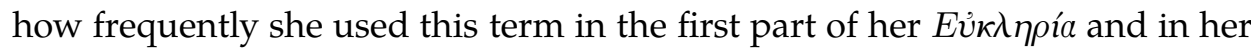
Opuscula $^{60}$. But in the Continuatio it is not present, which could possibly sustain the argument, that Van Schurman may not be the author of it. Although

\footnotetext{
55 De Imitatione Christi was first published in 1424. It is translated in many languages.

56 Eucl., 31.

57 Eucl., 23.

58 "Close reading of her Latin poems prove that she actually read some other Latin texts that were not suitable for her own high moral standards", Nagyillés 2018, 193.

59 Eucl., 21.

60 Eucl., 8, 21, 115, 125, 145, 150, 229, 240, 244, 249, 260, 272, 283, 288, 304, 318, 320. Opuscula 1648, De vitae termino, 7, 12, 23.
} 
the term itself is not present in the Continuatio, the idea is still there. For example the term 'goodness' is used for the meaning of 'providence' 61 . She also speaks of God's divine decision (Goddelijk besluit), but not in the meaning of the 'Decretum Horribile' in the doctrine of predestination ${ }^{62}$. As a child she knew exactly all the ins and outs of this doctrine and she was aware of all differences between 'Remonstrant' and 'Contraremonstrant'. In 1668 she had a discussion with Antoinette de Bourignon. She defended her views on predestination, in line with the Confessio Belgica, characterising herself as a 'strict Calvinist in the tradition of Dort' 63 . She trusted God's divine providence and embraced this principle of faith, as she showed in her letters to Claudius Salmasius ${ }^{64}$, to Dorothea Moore ${ }^{65}$, and to Anne de Merveil ${ }^{66}$. She was able to read the Bible in its original languages, and this opened for her the possibility of studying theology and philosophy. In the end she could read and express herself in many languages ${ }^{67}$. It was obvious: Si vir esset (if she had been a man), certainly she would have been a professor ${ }^{68}$.

\section{Longing to martyrdom}

In 1618 she read one of the books of martyrs, describing religious oppression. Numerous martyrs - in early Christianity and during the Reformation - were killed because of their faith or deviant convictions. Anna Maria was greatly impressed by reading it. Was it because of her own family relatives who had been religious fugitives? We do not know which Martyrbook she read ${ }^{69}$, but we do know that such books were very popular in those

61 Sometimes she used 'Godts goedertierenheit' (goodness), Cont., 1, 2, 4, 13, 14, 20, 39, 42, 61. 'Alzoo zijn ons dan door Godts goetheit alle dingen ons ten goede bestiert', 'Vaderlyke zorge Godts', Cont., 42.

62 Eucl., 227.

63 Schotel 1853, 247, Aanteekeningen, 43, 138-140; Irwin 1991, 308; De Baar 2004, 140.

64 Latin letter of March 1647, Opuscula 1648, 152.

65 Latin letter of 1 April 1641, Opuscula 1648, 197.

66 French letter of 13 August 1642, Opuscula 1648, 293.

67 Dutch, German, Italian, French, English, Greek, Latin, Hebrew, Chaldean, Aramaic, Arabic, Syrian, Persian, Samaritan and Ethiopian.

68 Barlaeus to Huygens (30 April 1636). "Si vir esset, posset lectiones professorum audire securius et inter eiusdem sexus studiosos sedere", Van Miert 2009, 145. Spang 2009, Wenn sie ein Mann wäre. Sneller 1992, 139-157.

69 Famous is John Foxe's Book of Martyrs, Actes and Monuments of these Latter and Perillous Days, touching Matters of the Church, 1563. 
days. Not only Protestants died for their faith, but also Roman Catholics, Anabaptists, and others ${ }^{70}$.

Young Anna Maria developed a strong desire to become a blood witness. She even wanted to die as a martyr, in her eyes a wonderful death ${ }^{71}$. She knew the words of Jesus to his disciples: "If anyone would come after me, let him deny himself and take up his cross and follow me. For whoever would save his life, will lose it, but whoever loses his life for my sake will find it"72. This longing for martyrdom remains a continuing feature in her life. Even on her deathbed she spoke of her willingness to suffer. She considered her sorrows as 'motes of the Cross', but only little ones ${ }^{73}$.

It was Anna Roemer Visscher ${ }^{74}$ who introduced her to the literary world of that time ${ }^{75}$. Honouring Jacob Cats Van Schurman wrote a poem for him in Latin when she was just fourteen ${ }^{76}$. In his turn in 1637 he praised her for her profound knowledge of theology ${ }^{77}$.

\section{Promise of celibacy}

She was nearly sixteen when her family went to Frisia in 1623 , settling in Franeker, where the famous Franeker Academy attracted many students ${ }^{78}$. Did she meet the Hungarian students who arrived in the same year? ${ }^{79}$ Her father Frederik van Schurman wanted to follow the lectures of the famous professor in theology Amesius, and her brother Johan Godschalk also ma-

70 Van Beek 2007², 17-18.

71 Eucl., 18.

72 Matt. 16:24-26. Translation ESV (English Standard Version).

73 Schotel 1853, 262.

74 In 1620 when Anna Maria was thirteen, the famous poet Anna Roemer Visscher (15841651) wrote a laudatory poem, praising her, calling her a friend. 'Zijt gegroet, ô jonge Bloem, van wiens kennis dat ik roem, Die ik acht en die ik minne, Die ik hou voor mijn vriendinne', Van der Stighelen 1987, 13.

75 Van Beek 2007², 20.

76 Opuscula 1648, 256-257.

77 Van Beek 2004, 16.

78 The Franeker Academy (founded 1585) was full of international students, and in 1623 the first Hungarian students arrived, Postma 2010, 19. Were they in contact with Anna Maria?

79 We do know she had in her library at least one Hungarian book, written by János Mikolai Hegedüs, Van Beek 2016,66. Hegedüs, Az mennyei igasságnak tüzes oszlopa, Utrecht 1648. Copy in UBVU: XZ.01722. 
triculated ${ }^{80}$. Her little brother Willem died in 1615 , but what about her other brother Hendrik-Frederik? We do not know if he was ever a student or what he was studying ${ }^{81}$. But we do know he never matriculated in Franeker. Was the family really living in the Voorstraat, in the so-called Martenahuis, as is often alleged, but without real evidence? Unfortunately her father Frederik died unexpectedly, just one week after his matriculation, coinciding with the date of his wedding day, also Anna Maria's birthday ${ }^{82}$. Normally a promise of celibacy is not typically Protestant. We do not know why it happened, but Van Schurman had to promise her father on his deathbed, that she would remain free of the inextricable, extremely perverted worldly chains of marriage ${ }^{\prime 83}$. She never married, but there were some rumours. Did Jacob Cats ask her to marry him, when she was fourteen? ${ }^{84}$ And was there a marriage with Jean de Labadie? ${ }^{85}$

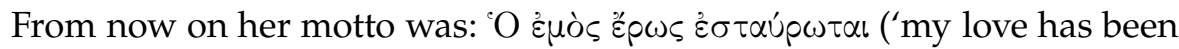
crucified'), a saying she adopted from Ignatius of Antioch, an early martyr ${ }^{86}$. It referred to her status of celibacy and to the crucifixion of Christ, but it is also an expression of her continued longing for martyrdom. Was she inspired by Protestant female martyrs such as Anne Askew (1520/21-1546), that holy

80 Both immatriculated 30-10-1623 - Nr. 2075: Fredericus a Schuirman, nobilis Coloniensis Nr. 2076: Johannes Godtschalcus a Schuirman, filius supradicti nobilis, Coloniensis. Album Studiosorum Franeker, 73.

81 "Son père [...] se transporta dépuis avec toute sa famille à Franequer pour y faire étudier ses deux fils", Paquot 1770, 658.

82 Anna Maria was born 5 November 1607, her parents married 5 November 1602, Frederik died 5 November 1623. This is the date on his gravestone in the Martinikerk in Franeker and it is confirmed by Duker 1914, 195. But the Van Schurman Family Bible, present in the Museum Martena in Franeker, gives the date of 15 November. I thank Manon Borst for sending a photograph of it. According to Schotel Frederik died 15 November and was buried 15 November, Schotel 1853, 85, Aanteekeningen, 48, which is impossible. Most researchers follow the date of 15 November. Van Beek 2016, 11, De Baar 2016, 119, Usakiewicz, Ocellus, 2019, 174. Is the problem caused by the introduction of the Gregorian calendar by Pope Gregorius XIII? The change from the Julian to the Gregorian calender caused a loss of ten days. The day after Thursday 4 October 1582 it was suddenly Friday 15 October. But Frisia did not follow the pope and introduced the Gregorian calender more than a century later (31 December 1700 / 12 January 1701).

83 Two erotic poems, attributed to her, are probably written by Vincent Fabricius. Van Beek, Liever een maagd, 2009, 345.

84 Graadt Jonckers 1843, 84; Schröck 1790, 152. Mollerus 1774, 808: Schurmanniam Labadio nupsisse, falso tradidit P.D. Huetius, Liber III, 50. Huetius 1718, 122. 
martyr in England? ${ }^{87}$ Or did she identify with the 'nine days queen' Lady Jane Grey (1537-1554)? Both women offered their lives for Christ. It should be mentioned here that Van Schurman later extolled Jane Grey ${ }^{88}$ as a martyr in her letters to both Elisabeth of Bohemia (7 September 1639), and to Dorothy Moore (8 August 1640) ${ }^{89}$.

After the death of Frederik van Schurman the family did not immediately leave Franeker. Her brother Johan Godschalk wanted to continue his studies there, so the family stayed a few more years. Did she meet the professors Amesius, Hachtingius, Dammius ${ }^{90}$ or Metius? ${ }^{91}$ Was she already in contact with Meinardus Schotanus? He inaugurated in 1626 in Franeker, and Van Schurman left the same year. Anyway they remained in contact. She contributed to the discussion he started in 1640 on the baptism for the dead $\left(1\right.$ Cor. 15) ${ }^{92}$. She made his portrait (1640), which is now in the Centraal Museum Utrecht, and she wrote an elegy after his death (1644) ${ }^{93}$.

\section{Pietas cum scientia coniugenda}

She was nineteen when the family returned to Utrecht in $1626^{94}$. She continued to build up many contacts with the scientific world of her time. Her brother Johan Godschalk wrote on 5 December 1629 to Caspar Barlaeus, stating that his sister was making good progress, that she had read his works, and that she wanted him to convey her greetings to him ${ }^{95}$. In 1631 she was in contact with the theologian Andreas Rivet and they remained friends till his death in $1651^{96}$. She developed intense correspondence with famous men, like Daniel Heinsius and Jacobus Revius and others. She also entered into a close

\footnotetext{
87 Classen 2014.

88 Usakiewicz, Ocellus 2019, 174.

89 Larsen 2016, 213.

90 Schotel 1853, 77.

91 Van Beek 2007², 27.

92 Van Beek 2004, 16. I could not verify it.

93 Epicedium in obitum Doctrina \& pietate Clarissimi viri D. Meinardi Schotani, in: Opuscula $1648,275-276$.

94 Van Beek 2007², 26. Witteveen gives 1632, Witteveen 1983, 396. In 2010 a tolling bell with her name was given to Utrecht University by the Utrechtse Klokkenluiders Gilde and placed in the little tower of the Academy Building.

95 'Totam iam illam habent tua scripta', Schotel 1853, Aanteekeningen, 112.

96 De Baar 2016, 121. Rang states they were already in contact 1628, Rang 1992, Een sonderlingen geest, 43. Spang states Rivet died 1650, Van Schurman/Spang 2009, LXVII.
} 
friendship with Elisabeth of Bohemia, who would later provide her and the Labadists with shelter. Van Schurman became very popular in scientific and royal circles and she was allowed to be part of the humanistic Republic of Letters ${ }^{97}$. She wrote many letters to learned women and men from different European countries. Only a part of this correspondence has been published ${ }^{98}$. She corresponded with Johan van Beverwijck and Constantijn Huygens ${ }^{99}$. Was she influenced by René Descartes? ${ }^{100}$ She definitely knew his work and she met him in 1635. He adored her, but in 1649 he visited her for the last time. He had no understanding or sympathy for her study of the Hebrew Bible. In his eyes it was a waste of time. Van Schurman was not amused; she disliked his concern for rationality and ended the relationship ${ }^{101}$.

The fact that she expressed her wish to study at the Utrecht University was very unusual for a woman in the $17^{\text {th }}$ Century. She was already familiar with the biblical languages and she really wanted to know more and more about the Bible. Gisbertus Voetius (1589-1676), a professor of theology and Eastern languages particularly recognised her talents. He was also interested in the balance between faith and science and wanted to keep both together. Pietas cum scientia coniugenda was the title of his inaugural lecture on the occasion of the foundation of the Schola Illustre in $1634^{102}$. Two years later he invited her to produce a laudatory poem in Latin, on the occasion of the opening of the Utrecht Academy in 1636. In this poem she mentioned the exclusion of women from universities. It drew a lot of attention and was immediately printed. The university made an exception for her personally and permitted her to be the first female student ever. Voetius encouraged her in the study of theology and fed her love for Hebrew and other ancient oriental languages. She was allowed to follow his lectures, on the condition that she should hide herself, in order not to draw male attention. She also followed lessons in literature and medicine.

97 Van Beek 1996, 36-49; Larsen 2008, 105-126; Norbrook 2003, 275-287.

98 The letters to Anne de Rohan (293-300), Bathusa Mackin (164-166), Elisabeth of Bohemia (281-287, 300-303), Madame Coutel (288-289), Anne de Merveil (289-293), Marie du Moulin (309-310), Marie le Jars de Gournay (318-320) are included in the Opuscula 1648.

99 Van Schurman, Van Beverwyck 1728. De Bruijn 2012, 153. Van der Stighelen 2009. Letters to Andreas Rivet (1573-1651), Andreas Colvius (1594-1671), Joh. van Beverwijck (15941647), Fr. Spanheim (1600-1649), Adolfus Vorstius (1579-1663), Claudius Salmasius (15881653), Jac. Cats (1577-1660), Daniel Heinsius (1580-1655), Const. Huygens (1596-1687) etc. are included in the Opuscula 1648.

100 Rang 1992, Een sonderlingen geest, 38; Roothaan 1992, 115.

101 Oprecht verhaal (Yvon) 1754, 122-123.

102 De Groot, De Jong 2001, 103. 


\section{Her faith always sought understanding}

As a student she was especially interested in Reformed theology, but not at the expense of her practical devotion and prayer. Theology was the queen of all sciences in those times. She tells us that she used to pray three times a day, like the prophet Daniel ${ }^{103}$. Sometimes she signed her work with the Calvinistic slogan 'Glory to God Alone', as we see on a sheet with Bible texts in Hebrew, Aramaic, Samaritan, Syrian, Arabic and Ethiopian, and the words Soli Deo Gloria ${ }^{104}$.

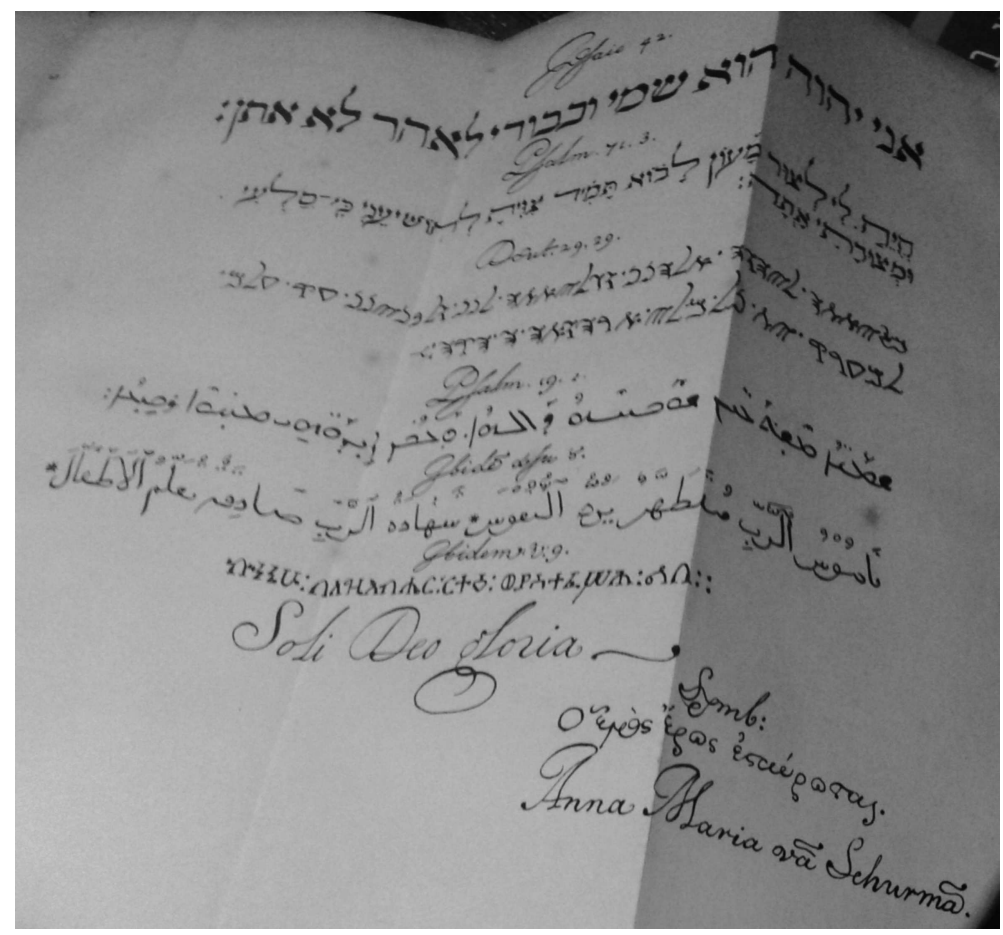

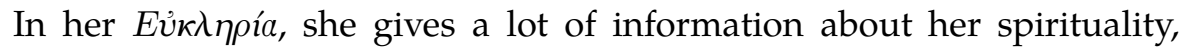
her faith, her theology and her philosophy. Her work is full of references to the Bible. On nearly every page we find a lot of biblical thoughts, quotations and expressions. It would be interesting to investigate in what way her use of the Bible is typical for her views of the Holy Spirit, her Christology and Ecclesiology, and how her choice of Bible quotations was influenced

103 Eucl., 84. In her Labadist period she stressed the need of praying whenever the Holy Spirit is present in your heart, Eucl., 86.

104 Van Beek 2007², 10. Schotel 1853, in between page 4 and 5 we find this multilingual sheet. 
by Pietism, Puritanism and Labadism. She used the expression the 'Shekel (scale) of the Sanctuary' (waagschale or weegschale or gewichte des heyligdoms) in order to evaluate things. This was quite a normal theologoumenon in the contemporary theology of her time ${ }^{105}$. She especially loved 'God's own language': Hebrew. Hebrew characters were even present in her embroidery. For her own use she wrote a draft for a grammar of the Ethiopian language in Latin ${ }^{106}$. Constantijn Huygens celebrated it in an epigram ${ }^{107}$, but unfortunately it is not preserved or even published? ${ }^{108}$ She was also interested in other religions. We know that she not only read the Koran more than once, but also copied it out by hand, an enormous achievement ${ }^{109}$.

One of Van Schurman's sources of inspiration was the church father Augustine (354-430). I think she herself is a good example of the Augustinian adagium: Credo ut intelligam, followed by Anselm (Fides Quaerit Intellectum). In her work she quoted Anselm at least one time and Augustine several times ${ }^{110}$. After her 'change', when she retracted all her earlier writings (1673), she also referred to Augustine's 'retractationes' from his Confessiones as her great example ${ }^{111}$. Yes, Christian faith is always her priority. In the end she complained, that she was renowned only for her intelligence, and that almost nobody had valued her faith (Godsaligheit). Was she famous only because she was a woman? Or because she hid her faith too much, she asked herself? ${ }^{112}$

105 Num. 7:13. Gewichte des Heyligdoms, Duker, 174; Weegschale des heiligdoms, Eucl., 14; Waagschale, Eucl., 60, 309; Koelman 1680; Artopé 1702; Schotel 1853, 193.

106 Schotel 1853, 35; Van Beek 2007², 70.

107 Huygens $1655^{2}, 369$.

108 Rang 1992, Een sonderlingen geest, 42.

109 Schotel 1853,34. It is preserved in the Staats-und Universitätsbibliothek Hamburg, Van Beek $2007^{2}, 244$.

110 Eucl., 14, 49, 63, 121, 147, 213. Schotel, 73, 81, 193. She mentions Augustine in her letter to Van Beverwijck, Opuscula 1648, 18. See the letters to Samuel Rachelius (Schotel Aanteekeningen, 131), to the Reverendo Viro D.S.R.S.D. (page 139) and to Bernardus Swalve (page 146). The Letters to Swalve (or Swaluwe) are translated in Dutch in 2010 by P. van Tuinen, http://www.vergetenharlingers.nl/page/17de-eeuw/\#brievenschurman, 03-02-2020. Also Usakiewicz describes the connection with Augustine, Ocellus 2019, 174, 183, 189. Van Beek, Klein werk, https://www.dbnl.org/tekst/beek017klei01_01/, 30-12-2019, page 73.

111 Douma 1924, 85. Eucl., 14. Augustine wrote: “Surgunt indocti et caelum rapiunt, et nos cum doctrinis nostris sine corde ecce ubi volutamur in carne et sanguine", Confessiones 1837, 134. Confessiones 1948, VIII, 19. Van Schurman quoted this text as follows "de eenvoudige en ongeleerde nemen den hemel in, en wy wentelen ons met geleertheit in vleesch en bloet, en worden in de Helle gestoten", Eucl., 63, translation A.C. Outler: "the uninstructed start up and take heaven, and we - with all our learning but so little heart- see where we wallow in flesh and blood!". Van Schurman added the sentence about hell.

112 Eucl., 19. 
In fact she always wrote openly about her faith in her letters and poems,

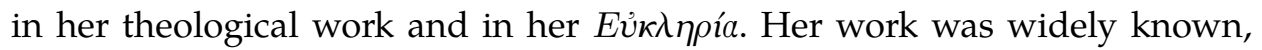
even in Roman-Catholic circles.

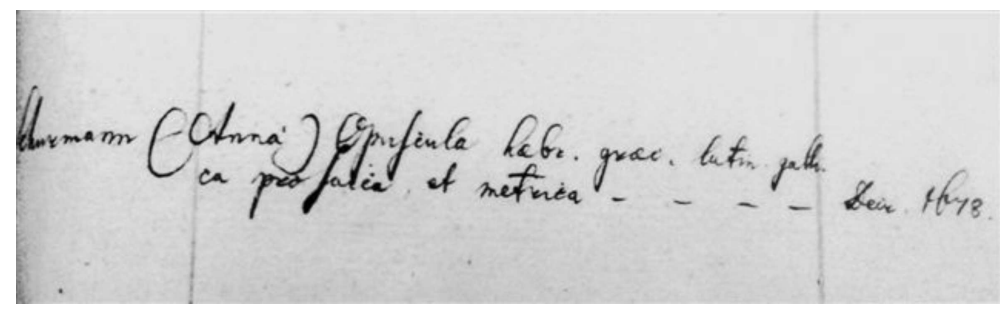

When I visited the Egyetemi Könyvtár (University Library) in Budapest in 2018, I discovered her name, included in the handwritten exemplar of the Papal Index there (1685), with as 'Argumentum' her Opuscula $16488^{113}$.

She always tried to be a good Christian. From the very beginning she was a pious girl with a certain aptitude for mysticism. As a theologian and as member of the Reformed Church she developed criticism on the bad state of the Reformed Church in those days. As a Labadist she was able to express her mystical feelings and high standards of a Christian life.

\section{De capacitate ingenii muliebris ad scientias}

Van Schurman wrestled with the question of universities not being open for clever women. She debated with Rivet about the question of whether or not it is allowed for a Christian woman to do scientific work. This correspondence was published for the first time in Paris ${ }^{114}$. Also an English edition appeared $^{115}$. For her it was evident that women are capable of doing so, therefore she pleaded eagerly for the right of Christian women to be accepted into universities. Her opponents raised a lot of objections. Education was not appropriate for Christian women; women were less naturally gifted than men. And why should women be educated at all, since they could not use their knowledge in practice? ${ }^{116}$ But Van Schurman raised her voice and showed her intellectual strength. Finally she defended her views in an essay

\footnotetext{
113 Index 1841, 352.

114 Colletet 1646; Dibon 1971; Bulckaert 1998.

115 Redmanye 1659.

116 Clarke 2013, 347-360.
} 
(Dissertatio 1641), in which she presented her arguments as syllogisms. She based her position on the authority of the Bible and on the Christian understanding of human nature. She defended the necessity of knowledge in order to acquire virtues. She had already made up her mind in her discussions with Dorothy Moore, Elisabeth of Bohemia and Marie le Jars de Gournay, and others ${ }^{117}$. She concluded that education was appropriate for both women and men. Her voice was so strong, her skills, her knowledge and her erudition were so obvious, that she was praised loudly. Voetius, Rivet and Spanheim were impressed and started to publish her work, mostly written in Latin. It was translated and reprinted many times. There were editions in the Netherlands, France and Germany. Her fame as the most erudite woman went all over Europe. But sadly none of her Italian and English contributions have been preserved.

\section{Is our human life and death determined by God?}

She dealt with several theological issues. Let us see how she handled the boundary between life and death. The physician Johan van Beverwijck had started in 1634 a discussion among scholars on the question of whether or not it was allowed to try to extend a person's life with the help of medical care $^{118}$. The question was: is the end of our lifetime predetermined by God? Is human medical action allowed or should we just obey God's will? Not only Calvinists contributed to this discussion, but also Remonstrants, Roman Catholics - and even the Jewish scholar Menasseh ben Israel - presented their opinions ${ }^{119}$. The latter published his contribution separately. So did Gisbertus Voetius ${ }^{120}$. Five years later, in her De Vitae Termino to van Beverwijck, Van Schurman presented her own view ${ }^{121}$. Although she admitted that God has exactly determined our lifetime in advance, she also stated that medical science is involved in God's plan. She even quoted the Koran (in Arabic), and translated it into Latin: Deus triumphat in sua causa, etiam homines plerique ignorant (God triumphs in his cause, even if the people do not understand it) ${ }^{122}$.

\footnotetext{
117 Le Jars de Gournay defended in 1622 equal rights for women and men: De l'égalité des hommes et des femmes.

118 Van Beverwijck 1634.

119 Van Beek 2007², 117; Menasseh ben Israel 1639.

120 Voetius 1641. I thank Dolf te Velde for his information.

121 Opuscula 1648, 1-27, but left out in the reprint of 1749 .

122 Van Beek 2007², 80.
} 
But in the eyes of the Lutheran professor Johann Conrad Dannhauer, who criticised her several times her interpretation on the divine providence was too fatalistic ${ }^{123}$. Providence can be interpreted as the idea, that God in his omnipotence arranges and decides everything, like a destiny against which all human agency is powerless. In this interpretation fatalism is inevitable indeed, but Van Schurman did not follow this interpretation. Dannhauer however reacted to her letter to Van Beverwijck and stated that she was obsessed by an absolute fatalism ${ }^{124}$. This 'Belgica Lachesis' (one of the three Fates) had written, that God's decree was fatal (Fatale decretum inevitabile est) ${ }^{125}$. He also named her the altera Clotha (also one of the Fates) and a filia fati ${ }^{126}$. This explains his saying, that it would have been better, if she 'had occupied herself with the spinning of hemp instead of working on the weaving of providence with her dangerous pen!' 127

\section{How Jesus healed a blind-born man}

Van Schurman also contributed to a discussion about illness and healing. For example her opinion was sought about the biblical story of the healing of the man born blind, told in John 9. Normally Jesus healed people only with his word. He never used any instruments. The question was raised: Why did Jesus use here clay, made of his own spittle? Did he create new eyes from the clay for this man? Did he do so in order to show his affinity or identity with God, the Creator, as in the beginning God created Adam of dust (Gen. 2:7)? Her correspondence with Van Beverwijck is preserved ${ }^{128}$. In her Question Letter (Vraaghbrief 1642) she does not give a real answer to this question. She argues that John 9 tells us how Christ healed the blind man, not by giving him new eyes (made from the clay of his spittle), as some church fathers like Cyprian thought. But the Evangelist did not say such a thing. He never said that our Saviour ever made or created parts of the human body or eyes. She refers to Hugo Grotius, who said that Christ used his spittle because there was no water available. And as ever she quotes

\footnotetext{
123 Schotel 1853, 84.

124 Dannhauer 1667, 175-178.

125 Opuscula 1648, 10.

126 Dannhauer 1654, 876-877.

127 Van Beek 2007², 173.

128 Van Beverwijck 1680, Aenhangsel, 192-201.
} 
Augustine. She argues that Christ did not heal the blind man by giving him new eyes, but by the opening of his eyes. In the end she only concludes: this was a great miracle worked by the mighty God.

\section{Baptism for the dead}

She was also involved in discussions around a really difficult Biblical problem, namely the meaning of the 'baptism for the dead' (1 Cor. 15:29). Many different interpretations are possible for this 'locus difficillimus' ${ }^{129}$. Do we have to interpret the word 'baptism' in a sacramental way here? Is it just a ritual cleansing with water? Or is it a sort of 'vicarious baptism'? Van Beek states that Meinardus Schotanus organised a debate on this subject ${ }^{130}$. Van Schurman's opinion was sought by the Reverend Jacobus Lydius, and she responded in Latin. Her letter to him (May 1640) on this subject is included in her Opuscula131. Lydius took her very seriously (he called her 'the miracle of our age'), and translated her letter, in part. We can find an abstract of it in his Vrolijke uren des doods ${ }^{132}$.

Van Schurman argues that it is necessary to interpret this text in the context of the resurrection, in which it is placed (1 Cor. 15). Apostle Paul first wants to defend the resurrection of the body, starting with the glorious risen Christ in the verses 1-28, and then (in verse 29) he speaks - in her opinion of the misery and humiliation of the apostles and church planters, who are suffering under persecution (1 Cor. 4:9). It seemed clear to her, that the word

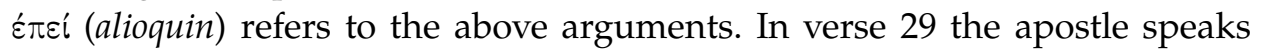
of those, who received baptism on behalf of the dead. He asks: "Other-

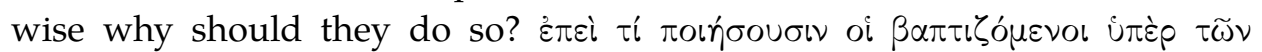

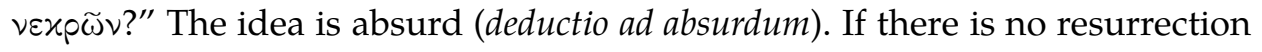
of the dead, the suffering of the Verbi Divini Ministri would be completely in vain. Their suffering 'for the dead' must be interpreted as 'on behalf of the faithful people' (pro mortibus, id est fidelibus), otherwise there would be no point in the suffering, or any hope (nulla spes gloriationis) in the day of the coming (adventu) of Christ. And in just this is the joy of the apostle (Phil. 2:16, 2 Cor. 1:14 and 4:14). Some could say: "It is sufficient for the

\footnotetext{
129 Letter to Cloppenburg, Opuscula 1648, 106.

130 See footnote 92 .

131 Letter to Lydius, Opuscula 1648, 98-105.

132 Lydius 1750, 214-217.
} 
church planters to know, that their souls receive blessed immortality". But Van Schurman thinks this is easily refutable, because of the verses 18-19133. Eternal salvation (aeterna salus) is at stake, not only for the body, but also for the whole person. This interpretation is - according to Van Schurman - not in opposition to the analogy of the faith or to the Holy Scriptures in general, or to the text itself ${ }^{134}$. The words 'the baptised' (oi $\beta \alpha \pi \tau \zeta \zeta$ ó $\left.\mu \varepsilon v o \iota\right)$ and $\beta \alpha \pi \tau \iota \zeta{ }^{\prime} \nu$ are used (per metaphoram) to express the immersion (baptism) in times of heavy prosecution (Matt. 20:22 and Luke 12:50) ${ }^{135}$. As Aben Esra interpreted Psalm 13:4, so Van Schurman quotes texts like Jer. 51:39, Psalm 124, Lam. 3:54, Rev. 12 and Psalm 69 about enemies, persecutions and dangerous floods of water as loca probantia. She quotes Sel. Jarchi and the Chaldee Paraphrastes

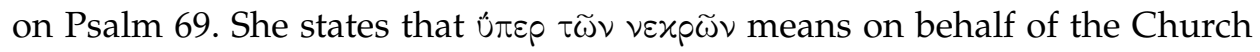
or the Elect and that this is often the meaning of the word úrep. She refers to 2 Cor.1:6, Eph. 3:13 and numerous other places. The apostle calls the Elect ironically the dead (Electos vero vocat mortuos per ironiam), just as the

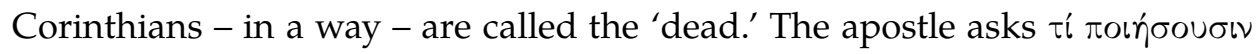

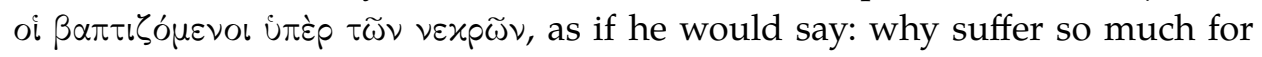
those who are already dead? Abraham, Isaac and Jacob are dead, but Christ said: they are living (viventes), because they will surely arise (Matt. 22:32). The dead will arise, so it is not strange that the same word (dead) is preserved here. Also the Greek particle $\tau \widetilde{\omega} \vee$ fits well (optime) in this interpretation. The word $\nu \varepsilon x p \widetilde{\omega} \nu$ does not mean all kinds of dead people, but it means a special 'branch' of the dead, namely the Elect. It is obvious that Verbi Divini Ministri, as protectors of the heavenly truth, suffer and endure a great deal for the salvation of other people, in the way orthodox interpreters defend it (in opposition to the bombastic interpretation of the Papists) with the words of the apostle (Col. 1:24, 2 Cor. 1:6, Phil. 1:14, 2 Tim. 2:9-10, and also Eph. 3:1, Col. 4:3, Acts $21: 28$ and 24:5). So be aware of the benefit, the comfort, the example of perseverance and the motivation of these oppressions. Look at the following verse (30): 'Why are we every hour in danger?' And see finally the apostle's own example (in the verses 31-32), where he says: 'I die every day'.

We have seen that Van Schurman rejects the common interpretation of 'vicarious baptism' in 1 Cor. 15. It was not only Lydius, who took her opinion

133 Lydius mentions the verses 8-9, but this is a mistake, 215.

134 According to Rang Van Schurman was opposed to the unity of body and soul (Letter to Colvius, 9 September 1637). Rang 1992, Een sonderlingen geest, 38. But the unity of body and soul here defended by Van Schurman, is in quite another theological context.

135 Matt. 20 however does not speak of baptism. Van Schurman meant probably the paralleltext: Marc. 10:38. 
seriously, but also Johannes Cloppenburg who did so by quoting her views ${ }^{136}$. In her letters to Cloppenburg she reaffirms her view ${ }^{137}$.

\section{Sacrifice - sanctification - self-denial}

For a long time she could afford her own lifestyle as a faithful intellectual, without many obligations, largely because she belonged to a well-to-do family. She had the privilege and the duty to develop herself in many ways. Her mother died in 1637 and then her life changed. Now she had new commitments ${ }^{138}$. Two of her mother's sisters, Agnes (ca. 1572-1661) and Sybilla von Harff (ca. 1574-1661), were growing older and needing her special attention and help ${ }^{139}$. Her obligations at home and her 'works of love' took much of her time, and so she missed the energy for her own artistic and scientific work. I think it can be overstated to say that the doctrine of sanctification became more important in her life ${ }^{140}$, but in her own eyes it was certainly

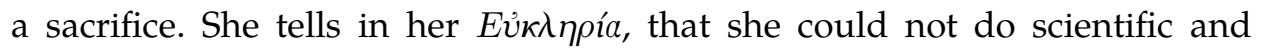
artistic work for nearly twenty years after her mother's death ${ }^{141}$, but in reality this was just partly the case. We know that some of her work was still published after her mother's death.

Could we see her promise to her father about celibacy (sacrifice of marriage 1623), her decision to take care of her aunts (sacrifice of ambition 1637), her decision to sell her house (sacrifice of property 1669) and her decision to join the Labadist movement (sacrifice of fame 1669) as a part of her principle of self-denial? ${ }^{142}$ Self-denial in her view belongs indeed to the essential ingredients of Christianity ${ }^{143}$. She made her own will in obedience and total compliance with God's will, thereby renouncing her former way of life ${ }^{144}$.

\footnotetext{
136 Van Beek 2007², 84.

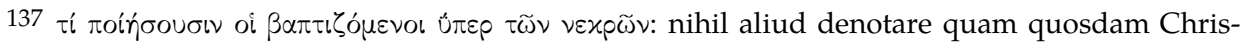
tianorum olim \& tunc temporis Baptismum recepisse; commotos scilicet exemplo istorum Martyrum, qui hanc veritatem proprio sanguine obsignaverant, Opuscula 1648, 107. See also Opuscula 1648, 199-202.

138 De Baar 1992, Eergeruchtje, 93-108, footnote 14.

139 Korte 1987, 38.

140 Scheenstra 1992, 124.

141 Eucl., 150.

142 A fine study on Van Schurman's self-denial is provided, Bo Karen Lee 2014.

143 Eucl., 78, 290.

144 She even speaks of the rests of her 'geestelijke gierigheid' (mental niggardliness) as a deviation of her self-denial, Eucl., 335.
} 


\section{Longing for the Holy City}

In the beginning of 1653 she moved to Cologne - the city where she was born - together with her brother Johan Godschalk and both their aunts. They wanted to claim back the family property which had been confiscated. But she could not really feel at home in this heavily Roman Catholic-dominated place. Reformed gatherings were still forbidden, so they had to cross over the Rhine to Mülheim in order to attend Protestant services there ${ }^{145}$. In 1654 she met some Roman Catholic scholars and had discussions with them. There were even rumours that she had converted and become a 'papist' 146 . She longed for the city of Utrecht and praised her old dwelling place as the holy city (Jerusalem) ${ }^{147}$. She was longing for the 'Holy City' in a double way. She was homesick for Utrecht, her friends, the good conversations, the brilliant preachers and pastors, who loved the church more than their own lives. But she was also longing for the spiritual coming of the Kingdom of Christ. One and a half years later it became time for her return to Utrecht. But homesickness can be a betrayal. Utrecht was no longer her 'Holy City'. There were quarrels and excommunications and problems about church properties. Van Schurman was very disappointed and complained that out of thousands of church members, she could not even find ten true believers ${ }^{148}$. In 1660 Anna Maria, with her brother and her aunts, decided to leave Utrecht and to move to a little village, Lexmond. There they stayed for two years. They organised a pious religious household, but lived a secluded life. Agnes and Sibylla both died in 1661. Now it was time for Johan Godschalk to travel to Germany and Switzerland in order to visit some important universities. He started a Peregrinatio academica ${ }^{149}$. Anna Maria went back to Utrecht.

\section{Mysterium Magnum}

Most researchers mention a booklet of 32 pages with the title Mysterium Magnum ${ }^{150}$. But only the pages $2-13$ are written by Van Schurman.

\footnotetext{
145 Van Beek 2007², 200.

146 Schotel 1853, 146.

147 See her poem on the differences between Utrecht and Cologne: 'O Utrecht lieve Stadt hoe soud ick u vergeeten', Van Beek 1992, Verbastert, 72.

148 Eucl., 205; Van der Linde 1978, 119.

149 Van Lieburg 1993, 59.

150 Schotel 1853, 234, Aanteekeningen, 41.
} 
We know this text from a German translation of 1699, but the poetic form of its original Dutch text is lost. The translation is based on a text of 1660, but I saw that the Short-Title Catalogue Netherlands surprisingly indicated that this text already appeared in the Dutch language in 1639 (Bedenckingen Aengaende de toekomste van Christi Coninkryk), but this has been corrected now ${ }^{151}$. The word 'bedenckingen' means: 'thoughts' or 'reflection' and does not have the connotation of 'concerns', as in Dutch nowadays. Is it true that this poem had been sung in a gathering of pious friends in the house of J. van Almeloveen on 15 September 1668? ${ }^{152}$ I know Van Schurman's didactic poem: Song, about the spiritual marriage of Christ with the faithful could be sung to the melody of Psalm 77 or Psalm $86^{153}$. Also her text of eight strophes against worldly companionship (Tegens werelts geselschap, 1677) fits on the melody of Psalm $86^{154}$. But because of the content it seems unlikely to me, that her Bedenckingen are used as a song text, with its 240 lines of poetry.

The Mysterium Magnum is addressed to all pious Christians, who love the presence of the Lord Jesus Christ. After the contribution of Van Schurman follows an overview of seven pages full of loca probantia defending Chiliastic ideas ${ }^{155}$. After that we should find a self-portrait of 'Anna Maria

151 The poem is present in the University Library of Amsterdam, but no date is given here. I saw that STCN gave the date 1639, https://books.google.nl/books?id=9xBjAAAAcAAJ\& printsec=frontcover, 24-02-2020, based on H.C. Rogge, Beschrijvende catalogus der pamflettenverzameling van de boekerij der Remonstrantsche Kerk te Amsterdam, 1862-1866. https://books. google.nl/books?id=04dWAAAAcAAJ\&hl=nl\&pg=PA248, 26-02-2020. Rogge seems to be based on Paquot, but there I could not find any proof. After my research in collaboration with Marja Smolenaars STCN changed the date. French version: Schurman, Pensées d'A. M. de Schurman Sur la Reformation necessaire à present à l'Eglise de Christ. Jacob van Velsen, Amsterdam 1669. Reprints: Bedenkingen van A.M. van Schuurman over de toekomste van Christi Koningryk, in: Heylige Lof-sangen ter Eeren Gods, tot Heerlijkheid van Jesus Christus, en tot Vertroostinge en vreugde van syn Kerk. Uit het Frans Vertaalt, Jacob van Velzen, Amsterdam 1675, 326-331. Bedenckingen van A.M. van Schurman over de Toekomste van Christi Coninkrijck, in: J. de Labadie, Heylige gesangen. Zijn achter bygevoegt de Bedenckingen van A.M. van Schurman over de Toekomste van Christi Coninkrijk, Jacob van de Velde, Amsterdam 1683, 394-400. Bedenkingen over de toekomste van Christus koningryk, in: F.A. Lampe, Verzameling van geestelyke gezangen, D. Rampen, F. Clement, Zwolle 1733. Bedenckingen over de toekomste van Christi Koninkrijck, in: H.W. Tydeman, B.F. Tydeman (ed.), Mnemosyne Deel V, Blusse en van Braam, Dordrecht 1825, 3-13.

152 De Baar 1992, Eergeruchtje, 177, footnote 58.

153 She wrote it probably before 1660, Van Beek 1992, Verbastert, 95.

154 Schurman $1681^{2}, 130-132$.

155 Mysterium Magnum 1699, 14-20. Friedrich Breckling (1629-1711) is quoted along with his book Christus Judex (1663). Also are mentioned Georg Lorenz Seidenbecher (1623-1663), Julius Sperber (1540-1616) and Johann Lobwasser. For Lobwasser see Heijting 2007, 228. 
von Schurmann' in a mirror, but it is missing in the exemplar I consulted. Nineteen points from page 20 to 24 praise all the linguistic, poetic, narrative and theological qualities of Van Schurman ${ }^{156}$. But also her philosophical, scriptural, medical and chemical knowledge, not forgetting her artistic and musical qualities, are praised. The laudatio ends with:

\section{Wer Zucht und Gottesfurcht in vollem Tugend Lichte /}

Wer Demuth ohne Falsch will abgebildet sehn

Hier kommt ein Engels Bild demselben zu Gesichte

Jungfer Schurmannin Ruhm, wird hier und dort bestehn

Then follows a description of the life of the first Christians. Is the Labadist community implied here? People were loving and caring. Each house was a church, an open house and a hospital. Ora et labora, but people were more in prayer (in Oratiorio) than working (in Laboratorio). Their theology was influenced by the Imitation of Christ and the lives of the Saints. Then follows a short enumerative description of the seven virtues of the Holy Spirit with loca probantia, closing with a prayer. Thereafter comes a letter (1 March 1690, Franckfurt) des weit und breit beruffenen Scheinheiligen Mannes D. Joh. Jacob Schüß to D. Johann Wilhelm Petersen ${ }^{157}$. Why is Schütz here described as a hypocrite? Schütz had contacts with radical Pietists, Chiliasts, Labadists, Mystics, Lutherans and Reformed people. He was the key figure in several networks ${ }^{158}$. Between 1674 and 1678 Van Schurman had a lively correspondence with him ${ }^{159}$. Reflected Van Schurman in the Mysterium Magnum on the decline of the Reformed Church? In a way this is true. She saw darkness, because the Church was dead, like a valley full of dry bones (Ezech. 37) ${ }^{160}$. It seemed as if Christ had left his church. But her text is also dogmatic theology in a nutshell, with a Christocentric and Chiliastic touch ${ }^{161}$.

\footnotetext{
156 In the methode of Theology, 'Dogmatica, Practica, Elenctica', Mysterium Magnum 1699, 22.

157 Petersen was Superintendent at Lüneburg.

158 Van de Kamp 2011, 346.

159 This correspondence is preserved in the University Library of Basel, Witteveen 1983, 399. https://www.e-manuscripta.ch/bau/doi/10.7891/e-manuscripta-52297, 20-02-2020.

160 Schurman, Mysterium Magnum 1699, 7.

161 Preexistence of Christ, two nature Christology, birth, suffering, death, resurrection and ascension of Christ, struggle with Satan, crone of thorns, crowns of holiness and glory, first and second Adam, Apocalyptic struggle, the coming Kingdom etc, it is all there.
} 


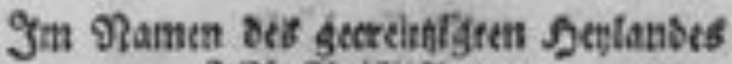

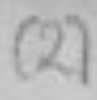

geit sbrifil amea

MYSTERIU M.MAGNUM,

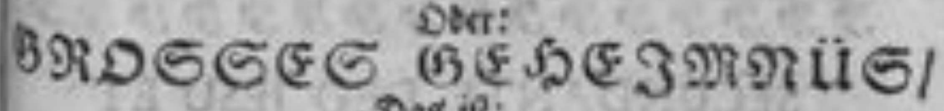
Dos ip:

Ein fofr ferrtides uns int betligen $230 r t$ ODtted woblgxgriabetes

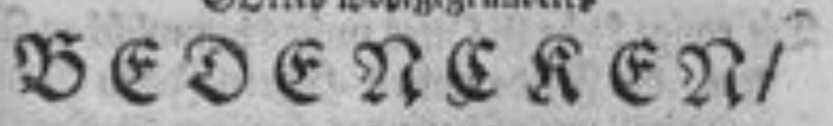

Hest ok 3utunfit bis

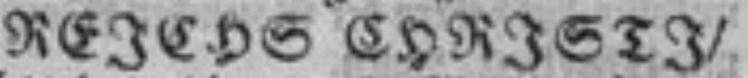

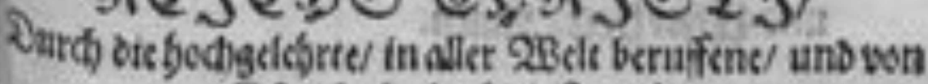

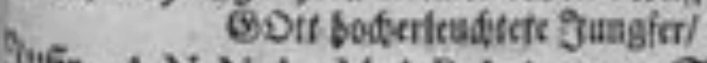

Tutif. A N N-A MAR I A von Sdurmann I

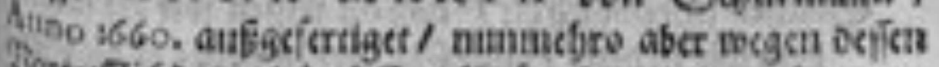

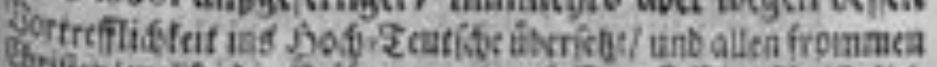

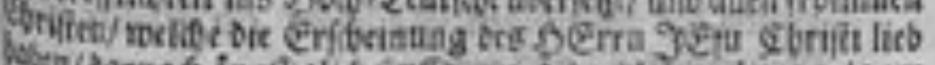

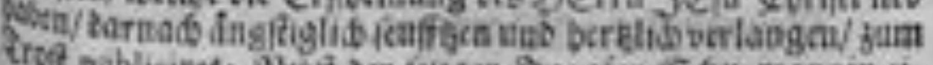

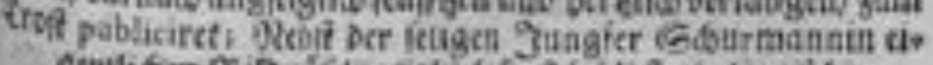

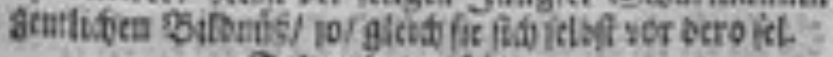

Sitiber Zoor abgemablet.

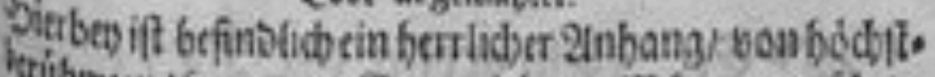

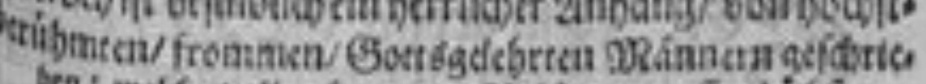

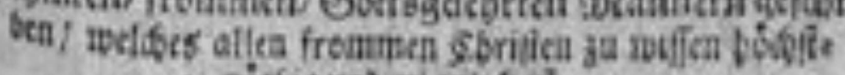
nitsig unb rredulite it.

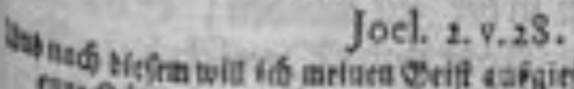

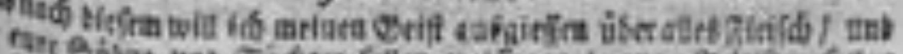

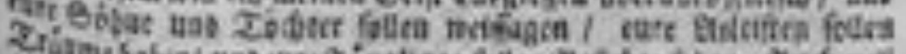

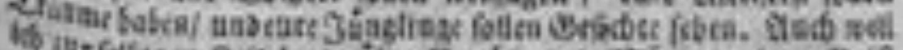

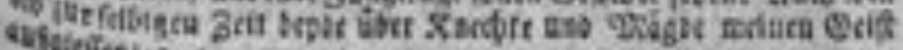
aseifitesis, $x$.

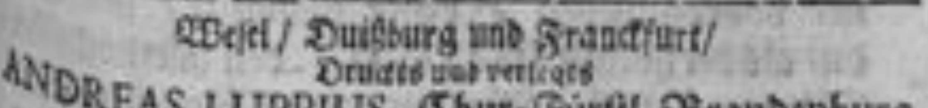

EAS LUPPIUS, Shure Sürft. Brandenburg. privileg. OuGbr. und Datbbiadier Dafilit.

Anno Chritti 1699. 


\section{The need of a new purifying strength}

It was the longing to a purified church that made her receptive for the ideas of Jean de Labadie ${ }^{162}$. He was "a minister of singular parts and of a convincing spirit" 163 . He published many texts for the international community and had many European contacts ${ }^{164}$. After his conversion to Protestantism he influenced Philip Jakob Spener in Germany ${ }^{165}$. In England John Milton was so impressed that he invited him to England. But Jean refused and went to Geneva, where he worked as a minister from 1659. His qualities as a preacher and a publisher were outstanding indeed. Already during his time in Switzerland De Labadie corresponded with Anna Maria van Schurman. Her brother Johan Godschalk was one of his admirers and it was through him Jean de Labadie came into contact with his sister. He spoke to her heart and to the hearts of many others who were sick of all the hypocrisy around, and who were longing to be a living church, where the Holy Spirit was clearly active.

In 1666 De Labadie was invited to the Netherlands, supported by many of his friends and connections in Utrecht. Johan Godschalk had already died. Gisbertus Voetius and Jodocus van Lodenstein ${ }^{166}$ were at his side, along with Anna Maria herself and they arranged his vocation. He was welcomed in the French speaking Walloon congregation of Middelburg, in the province of Zeeland, but without the consent of the regional church gathering. De Labadie was certainly not aware of that, but it had influence in his later dismissal. At first he was warmly welcomed there, as a kind of a second Calvin. This French speaking community in Middelburg was perfect for him, as he did not speak the Dutch language.

162 Born in France (1610), baptised in the Roman Catholic Church, Jean de Labadie joined the Order of Jesuits as a young man. The passion for Jesus Christ never left him. Attracted by the purifying strength of the Reformation, he became a Protestant in 1650. Two years later he gained the position of a preacher in Montauban. As a minister he enjoyed the teachings of John Calvin and other Reformers. He was talented, not to say a genius, and became highly influential.

163 Van der Wall 1988, 120.

164 As a Roman Catholic he enjoyed the special support of Cardinal Richelieu.

165 Scheenstra 1992, 126.

166 Larsen states, "that through her close acquaintanceship with Van Lodenstein, Van Schurman was prepared to receive the Labadist message", Larsen 2018, 305. 


\section{'On the sad decline of Christianity'}

The decline of the church in the Netherlands was a great sadness for Anna Maria, so she hoped that the new purifying strength of this new preacher would bring back the spirit of the Reformation. Also Voetius felt disappointed by the current situation of the church, and had great expectations of this Genevan preacher. Essenius and Koelman also supported him. He came to Middelburg, accompanied by three of his disciples: Pierre Yvon, Pierre du Lignon and Jean de Menuret. Because of his charisma, his strength and his enthusiasm, he was able to inspire many of his contemporaries. Van Schurman frequently visited Middelburg, because she was fascinated by him. But his outspoken personality made also enemies.

On 6 September 1665 Van Schurman wrote an alarming text in the form of poetry with the title On the sad decline of Christianity ${ }^{167}$. It is a lament on the corruption, the blindness, the hearts of stone and the errors of the Reformed Church, and its sleepy and undutiful pastors, who did not take care of the souls of their sheep. "They don't show the least bit of profound learning or natural eloquence. They are tasteless and do not smell as the oil of the Holy Spirit"168. She saw the church was in bad shape. "With what right could you name chaff wheat, even if there is a little grain in it? With what right could you name a whole flock of pigs a flock of sheep, even if some little sheep are walking amidst them"? ${ }^{169}$

\section{Different views on the Holy Scriptures - Birth of Labadism}

In 1668 there was a sharp theological conflict with a certain professor from Utrecht University, Lodewijk Wolzogen ${ }^{170}$. The conflict was about the latter's liberal view of the Holy Scriptures. De Labadie opposed him strongly and expected support from his Dutch colleagues. But this was not forthcom-

\footnotetext{
167 ‘Over het droevig verval der Christenen', Van Beek 1992, Verbastert, 126-131.

168 "niet alleen om dat' er zelfs niet een zier van grondige geleert-heit of van natuurlijke welsprekentheit in stak: maar wel voornaamlijk om dat ze niet een dropje smaakten of roken na die olie, welk de Geest Christi in de herten der zijne pleeg in te storten", Eucl., 38.

169 "Hoedanig het lichaam der Kerke is, want wie zou een hoop kaf, met eenig recht, een hoop terwe noemen, hoewel eenige weinige terwe granen daar onder mochten vermengt zijn ? of, wie zal een hele kudde Varkens een kudde: Schapen noemen, hoewel hy ziet, dat er hier en daar eenige weinige Schaapjes onderlopen?", Eucl., 157.

170 Gosker, Van Beek 2018, 10-12.
} 
ing. Even the congenial Voetianen did not support his position. Furthermore he got difficulties in the community of Middelburg because of his millenarian views. In 1669 De Labadie was forbidden to celebrate the Lord's Supper by his Synod and after a while he found himself dismissed. This was the end of his career as a Reformed minister and Labadism was born. De Labadie was not at all concerned about his dismissal. He went on preaching as if nothing had happened. The authorities forced him to leave Middelburg, so he fled to Veere, where he drew a great deal of attention. He was as successful and convincing as ever. Many curious people came from far and near to Veere to hear his sermons. This was not acceptable to the authorities, so he was forced to leave. He went to Amsterdam and soon he gained many supporters ${ }^{171}$. His personality always made a powerful impression arousing either support or opposition, but never quietness. The mayor of Amsterdam, Coenraad van Beuningen, supported him, but here again there were many opponents. So it was time to leave again.

\section{Decline of Christianity - Need of Reformation}

For Van Schurman all these new developments were very disappointing. She could not understand why Utrecht and the Voetianen could not support De Labadie in his efforts to reform the church. In her view this was so greatly needed. Also the criticisms of her learned and erudite friends could not change her mind. In 1665 she wrote a famous poem On the sad decline of Christianity: "Corrupted Christianity! Where is your former lustre of hope and faith? Why does your light shine so darkly?"172. In her opinion the light of the Gospel had been darkened through the reign of the Antichrist by numerous heresies, and the glow of Christian life had begun to diminish because of all the wickedness ${ }^{173}$. For a while she tried to convince her old friends. In 1668 for example she tried to mobilise the Frisian ministers by inviting them to a conference for a meeting of congenial minds, but it did not work. Her decision to leave the Reformed Church finally came in 1670. She sold most of her library, the house in Utrecht, the furniture and her

\footnotetext{
171 Schotel and others speak of 50 000, Schotel 1853, 205, but this is strongely overexaggerated.

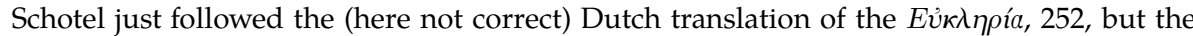
Latin original states just the opposite: just a few became Labadists, cf. Cannegieter 1897, 171.

172 Van Beek 1992, Verbastert, 126-131.

173 Eucl., 92.
} 
two certificates of deposit ${ }^{174}$, and went over to Labadism. She now lived in Amsterdam and from then on she was a part of the Labadist 'family'.

\section{Holy Restlessness}

The Labadists had ideas different from those generally accepted in mainstream orthodox Reformed views. They developed a new view on marriage ${ }^{175}$, they neglected the sacraments, they refused the baptism of children, they concentrated on chiliasm (i.e. the idea of Christ's expected return to

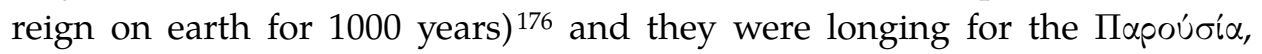
the so called second coming of the Lord Jesus Christ, in a way that was not acceptable to the established church. They denied the 'sufficientia' of the Bible, because of a strong emphasis on the Holy Spirit. The whole movement was full of 'holy restlessness'. They built up a loving community, where it was expected to share everything, not only the loving spirit of God, but also money and property. Labadism was striving to be a pure community of true believers, without any place for hypocrisy, laziness or indolence, and in the end it made a total break with the established churches. Van Schurman joined the Labadist community in 1669 . Soon afterwards, on 18 July 1670 the Church of Utrecht wrote her an official letter, asking her why she had left her church. Why did she not go to church in Reformed Amsterdam and why did she not take part in the celebration of the Lord's Supper? Her membership was still in Utrecht. Was she leaving her church because of Labadism or otherwise? The church was hoping that she should not encourage any separation, and ended with the heartily wish that she would come back ${ }^{177}$. On 5 August she wrote back (uyt Lexmonde) and answered with sadness, that it was not possible for her to stay in such a deformed church. She could not understand why the church of Utrecht did not ask for a more moderate approach concerning the innocent De Labadie and Yvon and their little orthodox community (kleine regtsinnige huijskerke). Why was this true servant of Christ excluded, whereas so many irregularities and heresies were tolerated? She could not accept the

174 Laurens 's-Gravensande bought her house on 24-12-1669, https://hetutrechtsarchief.nl/ component $/$ maisinternet $/$ ?mivast $=39 \&$ miadt $=39 \& \mathrm{mizig}=100 \&$ miview $=\mathrm{tbl} \& \mathrm{milang}=\mathrm{nl} \&$ micols=1\&misort=last_mod\%7Cdesc\&mip1=Schurman\&mip3=Anna\%20Maria\&mizk_alle =Schurman, 18-02-2020.

175 Verklaringe 1671, 91.

176 Scheenstra 1992, 132-134.

177 Duker 1887, 173-174. 
accusation of being a schismatic, because according to the Articles 27 and 28 of the Confessio Belgica she had to join the true church of Christ, even in its small form. She was not guilty of any schismatic action, which leads to the dissolution of the unity which Christians must keep - quoting Amesius. She hoped the church would take it all into consideration, serving the truth and using the 'scale of the Sanctuary' ${ }^{178}$. The answer came on 26 September, signed by Essenius. Her arguments had no effect. Utrecht had nothing to do with the excommunication of De Labadie. Her appeal to Amesius and the Confessio Belgica was to no avail. She should not support a schismatic movement. The letter ended with a passionate call to return to the Church of the Reformation ${ }^{179}$. But she did not do so. She followed Jean de Labadie for

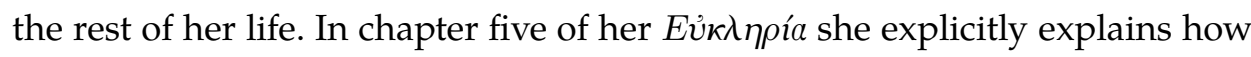
divine providence brought her through a miraculous and hidden way to her decision to join the true evangelical household of Christ. So she defended her choice for the Labadists with an appeal to divine providence, leading her to the purified gathering of true believers. She had decided to follow her admired preacher Jean de Labadie through thick and thin. Where he went, she went.

\section{To Herford and Altona - God's protection and punishment}

In 1670 the Labadists were a group of about fifty people, with Van Schurman among them. But there were troubles once more and the group had to leave Amsterdam. They went to Herford, in Germany, where they all stood under the protection of Elisabeth van de Palts, the abbess of a Protestant Women's Monastery. We know her as Elisabeth of Bohemia, one of Van Schurman's old friends. Elisabeth welcomed the Labadists, but after two years they had to leave Herford, because of the hostility of the local population. There must have been an Edict from the Emperor for the Labadists to leave Herford, but they did not do so immediately ${ }^{180}$. The reason for their departure was on the one hand the threat of a war, and on the other hand the absence of the 'Princesse' at the time. It was clear that dark times were approaching. After the Labadists left Herford a terrible period followed. No less than 5000 armed soldiers (from Münsterland) were billeted among the native Herford

\footnotetext{
178 Duker 1887, 174.

179 “Keert weder, Gij geliefde, keert weder", Duker 1887, 178.

180 Cont., 3.
} 
population, who had to feed them and to provide accommodation. Dirty infectious diseases claimed many victims ${ }^{181}$. Van Schurman saw it as God's punishment for all the sins of Herford, especially those of the Christians of the Augsburg Confession, who forced not only the Labadists, illegitimately, but also the Jewish people to pay high taxes ${ }^{182}$. In 1672 the Labadists settled in Altona, near Hamburg (belonging to Denmark at the time). Here she

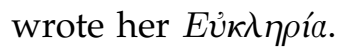

\section{The Sabbath}

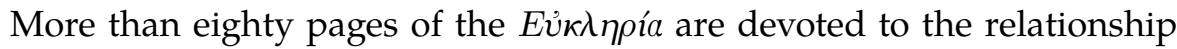
between Jewish and Christian understandings of the Ten Commandments, especially the meaning of the Sabbath and the nature of the Old and the New Covenants, which were popular issues. At first she seemed to dislike the idea that the Sabbath was only ceremonial and of no ethical validity for Christians ${ }^{183}$. She saw sharply the danger of neglecting Sunday's Sabbath rest and she stressed the importance of religious exercise in Sunday's services and prayers. She admired Theodorus à Brakel, who strictly kept all Sundays. But in fact he was not as rigid as she describes him in the Evंk $\lambda \rho^{\prime} a^{184}$. Her own position was - certainly after she read Calvin ${ }^{185}$ - more moderate. She opposed the strict position (overgelovig) as well as the relaxed one (reukeloos) and in the end she concluded: Is it not appropriate to serve God all the other days of the week and of your life? ${ }^{186}$ She also wrote a very short little poem on the Ten Commandments both in Hebrew and Dutch ${ }^{187}$.

Serve God alone, no image, save God's name, celebrate his rest, honour parents, murder nor adultery, nor steal nor lie, nor covet.

\footnotetext{
181 Cont., 5.

182 Cont., 4.

183 Eucl., 88. This was stated by Coccejus and Heidanus, but she does not mention the names of her opponents.

184 Eucl., 89. Visser 1939, 267.

185 She read Calvin's Institutio, II, VII, 34, a text she had earlier neglected, Eucl., 97.

186 Koelman classified her under the later opponents, Visser 1939, 249. Reitsma, Lindeboom $1916^{3}$, 622-638. J. Brown disagreed with her and wrote her a Latin letter in 1674. She answered his letter, but it is not preserved, Schotel 1853, 242.

187 Van Beek 1992, Verbastert, 65.
} 
Jean de Labadie died, exactly on his $64^{\text {th }}$ birthday. In the Continuatio we find a detailed memory of the last days of God's 'Special Servant'188. He died, because of his 'firm and indefatigable efforts in the vineyard of the Lord and his pastoral care, without taking any care of himself and his own health' 189 . He always tried to live and handle life as the first Christian community did (Acts 2-4). After the death of their leader in 1675 the Labadists returned to the Netherlands and from now on they lived in the Frisian village of Wieuwerd. Anna Maria died on 14 May 1678. She is buried in the church yard in Wieuwerd according to her final wishes. Her properties she left to the Labadists.

\section{Conclusion}

The way of life and the principles Jean de Labadie protected and defended, including his ecclesiological insights, were for Anna Maria van Schurman the fulfilment of her own faith and idealism: a pure life of reborn people ${ }^{190}$, connected to a strong belief in Jesus Christ, always trying to keep distance from those who were non-believers or just 'nominal-Christians' in order to prevent 'infection' or 'contamination'. As De Labadie left the Reformed Church in 1669, she was one of the first to join his separatist community, meeting in people's homes in the city of Amsterdam. What did she do after joining the Labadists? In what way did her theological insights and her mystical life change? What was the big change in her life and was it really such a radical break? This was indeed what she said herself about her 'excellent change' (veranderinge van mijn stant) ${ }^{191}$. This change brought her into a 'better' life. She departed from a 'worldly church' to a true Christian one ${ }^{192}$. Did she completely stop her scientific work and her work as an artist after her conversion? We know that is not true. She still made portraits - of Jean de Labadie of course - and she still wrote many letters and was studying theology. To a friend who wanted her judgement on some beautiful paintings, she answered that her heart was full of "another kind of paintings, in order to sketch the heavenly image of the divine virtues of King

\footnotetext{
188 Cont., 13.

189 Cont., 21.

190 Eucl., 153.

191 Eucl., 2.

192 Eucl., 151.
} 
Jesus, our Saviour, not by pencil on paper, but in my soul" ${ }^{193}$. Towards the

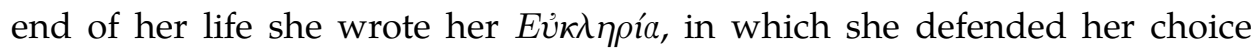
of the Labadists, in her eyes the true Church of Christ: 'the better part'. She refers to Maria ${ }^{194}$ (Luke 10:42), who also choose the best part (Mapià $\mu$ ràp

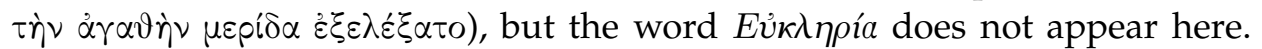

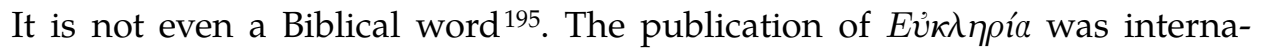
tionally not important. It did not draw much attention, although it is true that some Lutheran Pietists in Frankfurt am Main contacted Anna Maria

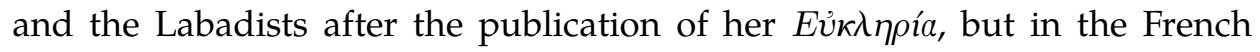
and English intellectual circles her work was not interesting any more. For Van Schurman her living faith was always hand in hand with her practical devotion and her openness for God, even in a mystical way. This is her experience in her Labadist period, but also we know, in her childhood and youth, she had mystical experiences. She took the risk of being 'over-religious', because she realised that was better than being with-

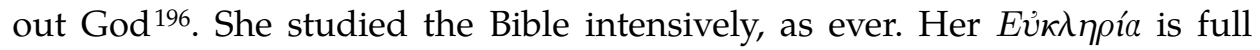
of biblical references and it would be worthwhile investigating these references, and the way they function for the whole of her theology. Many of her references are quite clear, especially if she refers to a specific text. But in other cases it takes a lot of work to figure out the Bible quotation and what might be her point? For example, it would be interesting to investigate her theological position concerning Jews and Judaism ${ }^{197}$. Is she influenced by Voetius here? She names the Jewish religion 'childish' and full of 'outward appearances'198. She calls the Jewish people 'servient' and 'looking for wage'199. She hopes the Jewish people will be converted to Christianity ${ }^{200}$. Is there a glimpse of anti-Semitism in it? This suggestion is denied

\footnotetext{
193 Eucl., 32.

194 Eucl., Van der Linde, Preface, sine numero.

195 Eủxinpí $\alpha$ means 'good luck in drawing lots'. As far as I know the word Eủxinpia is used in ancient Greek just one time (by Libanius, ca 314-393). Liddell-Scott, A Greek-English Lexicon, Clarendon Press, Oxford 1973, 78. Van Schurman herself translates 'heilzaam lot', Eucl., 199.

196 Eucl., 92.

197 Eucl., 90-116; 140-158.

198 Eucl., 25.

199 Eucl., 90, 91.

200 Van Beek 1992, Verbastert, 89: “Sal niet aen Israel sich Christus openbaren, En dan sijn oude volk sich Christenen verklaren, En zeeg'nen die daer komt tot haer in 's HEEREN Naem, En soo 't verstoten volk weer worden aengenaem?".
} 
by Goldman ${ }^{201}$. Also Van Campen denies anti-Semitism in the thoughts of the followers of Voetius ${ }^{202}$.

Van Schurman is characterised in a biblical way as a 'tree, planted by streams of water' (Psalm 1), as Martha/Maria together (Luke 10:38-42), as a help for the poor as Dorcas (Acts 9:36-43), as a good Samaritan (John 4) ${ }^{203}$. Why did she rarely mention famous Biblical women in her work (apart from Eva, Sara, Maria and the Samaritan woman)? ${ }^{204}$ Was she really so impressed by the story of Paula and Eustachium (who followed Hieronymus to Bethlehem), that it led to her final decision to become a Labadist? ${ }^{205}$ The Labadist movement had no more than 400 followers at any time. Still the movement had enormous effects, positive as well as negative. Some devoted supporters changed their mind after a while, and became strong opponents. They were impressed by De Labadie, but in the end could not approve of his separatism and - above all - they could not approve of his ecclesiastical ideas about what a church should be. Many theologians felt they had to oppose him and they did so with passion ${ }^{206}$. Voetius thought it was outrageous to leave the church only because of some 'scabby sheep', in order to be 'clean' or 'spotless' oneself. But Van Schurman felt attracted to the Labadists, especially because of the charismatic leadership of Jean de Labadie, who never compromised. The names of Jean de Labadie and Anna Maria van Schurman are connected by unbreakable bonds forever. As a young woman she wrote many letters and she published texts in different fields, mostly from a pious and biblical point of view. Her feminist views remained within the accepted borders of her time. Also her artistic life was for the glory of God. As an elderly woman she confessed that she wanted to praise the Lord, not by pencil on paper, but in her life and soul.

\section{Bibliography}

Artopé, Jacob, Weegschaal des heyligdoms [...], Breda 1702.

Augustinus, Aurelius, Confessiones, C.H. Bruder (ed.), Lipsiae 1837.

\footnotetext{
201 Goldman 1999, 165.

202 Van Campen 2006, 272.

203 Schotel 1853, 140, 196.

204 Eva, Eucl., 108, Zara, Eucl., 159. Samaritan woman, Eucl., 124.

205 Schotel 1853, 189.

206 Jacobus Koelman, Willem à Brakel, Gisbertus Voetius, Jacobus Borstius, Petrus Dittelbach, Johannes van der Waayen, Herman Witsius.
} 
- Augustinus' Confessiones, latijnsche tekst met vertaling van A. Sizoo, Meinema, Delft 1948.

Baar, Mirjam de, e.a. (ed.), Anna Maria van Schurman (1607-1678), een uitzonderlijk geleerde vrouw, Walburgpers, Zutphen 1992. English translation: Choosing the better part. Anna Maria van Schurman (1607-1678), Kluwer Academic Publishers, Amsterdam 1996.

Baar, Mirjam de, 'Wat nu het kleine eergeruchtje van mijn naam betreft'... De Eucleria als autobiografie, in: M. de Baar, e.a. (ed.), Anna Maria van Schurman (1607-1678), een uitzonderlijk geleerde vrouw, Walburgpers, Zutphen 1992, 93-108.

- Prophetess of God and prolific writer, Antoinette de Bourignon and the reception of her writings, in: S. van Dijk e.a. (ed.), I have heard about you: Foreign women's writing crossing the Dutch border, Verloren, Hilversum 2004, 137-150.

- Anna Maria van Schurman (1607-1678). Internationale beroemdheid in de Gouden Eeuw, venster in de Canon van Friesland, in: H. Oly, G. de Vries, Leeuwarden in de Gouden Eeuw, Verloren, Hilversum 2016, 111-132.

Baar, Mirjam de, Brita Rang, Minerva of Savante, heilige of dweepster? Receptiegeschiedenis van Anna Maria van Schurman sedert de zeventiende eeuw, in: M. de Baar e.a. (ed.), Anna Maria van Schurman (1607-1678), een uitzonderlijk geleerde vrouw, Walburgpers, Zutphen 1992, 9-28.

Beek, Pieta van (ed.), Verbastert Christendom. Nederlandse gedichten van Anna Maria van Schurman (1607-1678), Den Hertog, Houten 1992.

- Een Vrouwenrepubliek der letteren? Anna Maria van Schurman (1607-1678) en haar netwerk van geleerde vrouwen, in: Tydskrif vir Nederlands en Afrikaans, 3, 1996, 1, 36-49.

- Klein werk: de Opuscula Hebraea Graeca Latina et Gallica, prosaica et metrica van Anna Maria van Schurman (1607-1678), 1997, URL: www.dbnl.org.

- 'Poeta laureata': Anna Maria van Schurman, de eerste studente in 1636 [...], Utrecht 2004.

- De eerste studente: Anna Maria van Schurman (1636), Matrijs, Utrecht $2007^{2}$.

- Liever een maagd dan een weduwe: twee erotische gedichten op naam van Anna Maria van Schurman (1607-1678), in: Tydskrif vir Geesteswetenscappe, 49, 2009, 333-349.

- 'Habent sua fata libelli': the adventures and influence of Anna Maria van Schurman's work in Scandinavia, in: A. Steiner-Weber (ed.), Acta Conventus Neo-Latini Upsaliensis, I, Leiden/Boston 2012, 199-209.

- On God. An unknown florilegiun of Anna Maria van Schurman (ca. 1625), Provily Pers, Ridderkerk 2014.

- Het is dezelfde geest waardoor ik leef en ademhaal. De spiritualiteit van Anna Maria van Schurman (1607-1678), in: J. van Amersfoort, P. van Beek, G. Schutte (ed.), Ora et labora: Twaalf opstellen over christelijke spiritualiteit in de praktijk, Verloren, Hilversum 2014, 45-62.

- Uw lieftallige brief. Een onbekende brief van Anna Maria van Schurman aan Johannes Vollenhove (1668), Provily Pers, Ridderkerk 2014. 
- Verslonden door zijn liefde. Een onbekende brief van Anna Maria van Schurman aan Petrus Montanus (1669), Provily Pers, Ridderkerk 2015.

- Ex Libris. De bibliotheek van Anna Maria van Schurman en de catalogi van de Labadistenbibliotheek, met medewerking van Joris Bürmann, Provily Pers, Ridderkerk 2016.

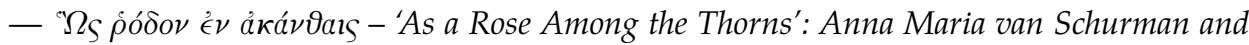
her correspondences in Greek, in: J. Päll, I. Volt, Hellenostephanos. Humanist Greek in Early Modern Europe: Learned Communities between Antiquity and Contemporary Culture, Acta Societatis Morgensternianae, VI-VII, University of Tartu Press, Tartu 2018, 414-437.

Beverwijck, Johan van, Epistolica quaestio de vitae termino, fatali an mobili? [...], Henricus Essaeus, Dordrecht 1634 (secunda editio, Joannis Maire), Lugduni Batavorum 1636.

- Van Beverwijck's wercken, Geneeskonste, bestaende in den Schat der Gesontheyt, schat der ongesontheyt, heel-konste, mitsgaders eenige tractaten [...], met Aenhangsel, Schipper, Amsterdam 1672.

Breckling, Friedrich, Christus Judex, In \& cum Sanctis contra Gentes, secundum Judicium $\mathcal{E}$ Justitiam. Das Geheimnis des Reichs von der Monarchi ChriJti auf Erden, [...], Ev. Prediger in Zwol, s.l. 1663.

Brouwer, Marjan, Vrouw van de wereld. Het leven van Anna Maria van Schurman, Museum Martena, Franeker 2007.

Bruijn, Enny de, Eerst de waarheid, dan de vrede. Jacob Revius 1586-1658, Boekencentrum, Zoetermeer 2012.

Birch, Una, Anna Maria van Schurman: artist, scholar, saint, Longmans, Green and CO, London/New York/Bombay/Calcutta 1909.

Campen, Mathijs van, Gans Israël. Voetiaanse en coccejaanse visies op de joden gedurende de zeventiende en achttiende eeuw, Leiden 2006.

Cannegieter, T., Eene zonderlinge vergissing betreffende de geschiedenis der Labadisten te Amsterdam, in: Archief voor Nederlandsche Kerkgeschiedenis, 6, 1897, 161-173.

Clarke, Desmond, Anna Maria van Schurman and Women's Education, in: Revue Philosophique de la France et de l'Étranger, 2013, 3, Tome 138, 347-360.

Classen, Albrecht, (ed.), Mental Health, Spirituality, and Religion in the Middle Ages and Early Modern Age, De Gruyter, Berlin/Boston 2014.

Dannhauer, Johann Conrad, Hodomoria Spiritus Calviniani, Duodecim Phantasmatis, Academica parrhesia ac philalethea, Argentorati 1654.

- Libri Conscientiae, Tomus posterior, Spoor, Argentorati 1667.

Dibon, Paul, in co-operation with E. Estourgie, H. Bots (ed.), Inventaire de la correspondance d'André Rivet (1595-1650), The Hague 1971.

Douma, Anna Margaretha Hendrika, Anna Maria van Schurman en de studie der vrouw, Amsterdam 1924.

Duker, Arnoldus Cornelius, Gisbertus Voetius, Derde deel (Hoogleeraarschap, 1634-1676), Brill, Leiden 1914. 
- Briefwisseling tusschen den Utrechtschen Kerkeraad en Anna Maria van Schurman, in: Archief voor Nederlandsche Kerkgeschiedenis, 2, 1887, 171-178.

Eck, Caroline van, Het eerste feministische tractaat? Anna Maria Vn Schurmans verhandeling over de geschiktheid van vrouwen voor de wetenschapsbeoefening, in: M. de Baar, e.a. (ed.), Anna Maria van Schurman (1607-1678), een uitzonderlijk geleerde vrouw, Walburgpers, Zutphen 1992, 49-60.

Goebel, Max,Geschichte des Christlichen Lebens in der rheinisch-westphälischen evangelischen Kirche, Zweiter Band. Das siebenzehnte Jahrhundert oder die herrschende Kirche und die Sekten, Coblenz 1852.

Goldman, Shalom, Spiritual Feminism and Christian Hebraism: Women and the Study of Hebrew in Seventeenth Century Europe, in: Hebrew Studies, 40, 1999, 153-168.

Gosker, Margriet, Pieta van Beek, Anna Maria van Schurman als Labadiste, in: Handreiking 48, 2018, 5, 10-12.

Graadt Jonckers, Roelof Hendrik, Anna Maria Schurman in haar Christelijk karakter vergeleken met Christina Koningin van Zweden, in: D.J. Haspels (ed.), Eukleria of de goede keuze. Christelijk volksboekje voor het jaar 1844, Haspels, Nijmegen 1843.

Groot, Aart de, Otto J. de Jong, Vier eeuwen theologie in Utrecht. Bijdragen tot de geschiedenis van de theologische faculteit aan de Universiteit Utrecht, Meinema, Zoetermeer 2001.

Houbraken, Arnold, De groote schouburgh der Nederlantsche konstschilders en schilderessen [...], zynde een vervolg op het Schilderboek van K. v. Mander, Deel I, Amsterdam 1718.

Huetius, Petrus Daniël, Commentarius de rebus ad se pertinentibus, Henricus du Sauzet, Amsterdam 1718.

Huygens, Constantijn, Momenta desultoria poëmatum, libri XIV, Editio altera, [...], Ex Typographia Adriani Vlacq, Hagae-Comitum $1655^{2}$.

Index Librorum Prohibitorum Sanctissimi Domini nostri Gregorii XVI Pontificis Maximi Jussu editus, Thomas Anthonius Degola (ed.), Romae 1841, 352.

Irwin, Joyce, Anna Maria van Schurman and Antoinette Bourignon: Contrasting Examples of Seventeenth-Century Pietism, in: Church History, 60, 1991, 3, 301-315.

Jacob, Ludovicus, Elogium erudissimae virginis Annae Mariae a Schurman, Batavae, in: Question Celebre. S'il est necessaire, ou non, que les Filles soient sçavantes, Paris 1646, 83-98.

Koelman, Jacobus, De weegschaal des Heyligdoms omtrent de feestdagen der Gereformeerde Kerk in Nederland [...], Amsterdam 1680.

Kamp, Jan van de, 'auff bitte und einrahten etzlicher frommen Menschen ins hochteutsche ubersetzet'. Deutsche Übersetzungen englischer und niederländischer reformierter Erbauungsliteratur 1667-1697 und die Rolle von Netzwerken, Dissertatie Vrije Universiteit, Amsterdam 2011.

Korczak-Siedlecka Jaśmina, Anna Maria van Schurman i walka o dostęp kobiet do edukacji w XVII wieku, in: Rocznik Filozoficzno-Społeczny Civitas Hominibus, 11, 2016, $19-24$. 
Korte, Annemarie, Verandering en continuiteit. Over de ommekeer van Anna Maria van Schurman en Mary Daly, in: Mara. Tijdschrift voor feminisme en theologie, 1, 1987, 35-44.

Larsen, Anne R., A Women's Republic of Letters: Anna Maria van Schurman, Marie de Gournay and Female Selfpresentation in Relation to the Public Sphere, in: Early Modern Women: An Interdisciplinary Journal, 3, 2008, 105-126.

- Anna Maria van Schurman, 'The Star of Utrecht'. The educational Vision and Reception of a Savante. Women and Gender in the Early Modern World, Routledge, London/New York 2016.

- Religious Alterity:Anna Maria van Schurman and Jean de Labadie, in: French Forum, 43, 2018, 2, 301-317.

Lee, Bo Karen, Sacrifice and Delight in the Mystical Theologies of Anna Maria van Schurman and Madame Jeanne Guyon. Studies in Spirituality and Theology, University of Notre Dame Press 2014.

Lieburg, Fred A. van, Johan Godschalk van Schurman (1605-1664), in: J.B.H. Alblas e.a., Figuren en thema's van de Nadere Reformatie, Deel 3, Lindenberg, Rotterdam 1993, 55-68.

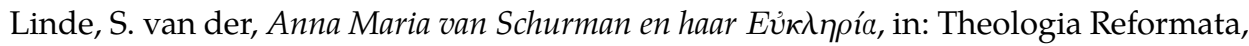
92, 1978, 117-144.

Lobwasser, Johannes, Einige kurtze Anweisungen / Aus dem Reichthum und Uberfluß der heiligen Schrifft; Belangend das herrliche Reich Christi / Welches noch vor dem letzten und jüngsten Gericht auff Erden kommen soll, Frankfurt 1674.

Lydius, Jacobus, Vrolicke uren des doods, first edition 1640. Reprint: Vrolijke uren des doods, Abraham Blusse, Jakobus van Hoogstraten, Dordrecht 1750.

Maas, Margot, Als een spin in het web. Een comparatief onderzoek naar de brieven van Anna Maria van Schurman (1607-1678) gericht aan mannen en aan vrouwen, Scriptie Radboud Universiteit, Nijmegen 2016.

Marnef, Guido, Antwerpen in de tijd van de Reformatie. Ondergronds protestantisme in een handelsmetropool 1550-1517, Meulenhoff, Amsterdam 1996.

Menagius, Aegidius, Historia mulierum philosopharum, Leiden 1690.

Menasseh ben Israel, De termino vitae: Libri tres. Quibus veterum Rabbinorum, ac recentium doctorum, de hac controversia sententia explicatur, Amsterdam 1639.

Meyer, Diemut, Anna Maria van Schurman, Frauen müssen ihre Geschichte selbst überliefern, damit sie nicht in Vergessenheit gerät, http://frauen-und-reformation.de/?s $=$ bio\&id $=61$.

Miert, Dirk van, Humanism in an Age of Science: The Amsterdam Athenaeum in the Golden Age (1632-1704), Brill, Leiden 2009.

Mollerus, Johannes, Cimbria literata sive scriptorum Ducatis utriusque Slesvicensis et Holsatici, Hafniae 1744, 805-817.

Nagyillés, János, Vel non legi, vel saltuatim tantum: Megjegyzések Anna Maria van Schurman latin nyelvú költeményeihez, in: Antikvitás \& Reneszánsz, 1, 2018, 2, 193-204. 
Norbrook, David, Autonomy and the Republic of Letters: Michèle Le Doeuff, Anna Maria van Schurman and the History of Women Intellectuals, in: Australian Journal for French Studies, 40, 2003, 275-287.

Oprecht verhaal van het leven, gedrag en gevoelen van wylen den heer Joh. de Labadie, uit het Fransch vertaalt te Amsterdam, gedrukt in het jaar 1754, Amsterdam 1754 (Pierre Yvon). In this edition is the Dutch version of the Continuatio included, 235-307.

Paquot, Jean Noël, Mémoires pour servir à l'histoire littéraire des dix-sept provinces des Pays-Bas, de la principauté de Liége, et de quelques contrées voisines, Tome III, l'imprimerie Academique, Louvain 1770.

Postma, Ferenc, Als ballingen aan de boorden van de Amstel, in: M. Kun, J. Morvai (ed.), לכבוד ספר Marjovszky Tibor נ, Tanulmánykötet Marjovszky Tibor 50. születésnapja alkamáb/ol, Budapest 2003, 196-211.

- De Hongaren en het onderwijs aan de Universiteit te Franeker, in: It Beaken, 72, 2010, $1 / 2,19-54$.

Postma, Ferenc, Arian Verheij, In signum benevoli affectus I. Seven Album inscriptions by Menasseh ben Israel, in: Zutot. Perspectives on Jewish Culture, 6/1, 2009, 35-47.

Prößdorf, Detlef e.a., Blaukopp - 200 Jahre Protestanten in Köln, Eigenverlag, Köln 2002.

Puyl, Gerard van der, Kort verhaal ter elucidatie voor de heeren leden van de commissie van kunsten en wetenschappen bijeen verzameld uit de notulen, Utrecht 1806.

Rappard, Frans Alexander van, Overzigt eener verzameling Alba Amicorum uit de XVI en XVII eeuw, Volume 7, No 2, Deel 1, Nieuwe Reeks van werken van de Maatschappij der Nederlandsche Letterkunde, Leiden 1856.

Reitsma, Johannes, Johannes Lindeboom, De Hervorming en de Hervormde kerk der Nederlanden, Kemink \& Zoon, Utrecht $1916^{3}$.

Reuver, Arie de, Vroomheid die grenzen overstijgt. Voor-reformatorische bronnen van het Nederlandse gereformeerd protestantisme, in: H.A. Speelman, K. van der Zwaag (ed.), Spirituele oecumene. Over de vele vormen van de gezamenlijke en persoonlijke omgang met God, Summum Academic Publications, Kampen 2019, 658-666.

Roothaan, Angela, Caroline van Eck, Anna Maria van Schurman's verhouding tot de wetenschap in haar vroege en late werk, in: Algemeen Nederlands tijdschrift voor wijsbegeerte, 82, 1990, 194-211.

Roothaan, Angela, Anna Maria van Schurmans hervorming van de wijsbegeerte, in: M. de Baar e.a. (ed.), Anna Maria van Schurman (1607-1678), een uitzonderlijk geleerde vrouw, Walburgpers, Zutphen 1992, 109-121.

Schotel, Gilles Dionysius Jacob, Anna Maria van Schurman, Gebroeders Muller, 'sHertogenbosch 1853.

Schmidt, Klaus, Aufstieg einer Minderheit. 500 Jahre Protestanten in Köln, Lit. Verlag Dr. W. Hopf, Berlin 2016.

Schröck, Johann Matthias, Lebensbeschreibungen berühmter Gelehrten, Vol. 2, Schwickert, Leipzig 1790. 
Schurman, Anna Maria van, De Vitae Termino, in: Opuscula 1648,1-27. Dutch translation: Paelsteen van den tijt onses levens, Jasper Gorissz, Dordrecht 1639 and 1639², Amsterdam 1639, Amsterdam 1647, Dordrecht 1651. German translation, Der Marckstein vom Ziel und Zeit unseres Lebens, s.l. 1679. French translation, Rebuffé, Paris 1730.

- Amica Dissertatio inter Annam Mariam Schurmanniam et Andr. Rivetum de capacitate ingenii muliebris ad scientias, Paris 1638.

- Dissertatio de ingenii muliebris ad doctrinam et meliores litteras aptitudine. Accedunt Quaedam Epistolae eiusdem Argumenti, Elzeviriana, Lugdunum Batavorum 1641.

- Guillaume Colletet (ed.), Question celèbre, s'il est nécessaire ou non que les Filles soiens Sçavantes. Le tout mis en François par le Sr. Colletet, Rolet le Duc, Paris 1646.

- John Redmayne (ed.), The Learned Maid, or Whether a Maid may be a Scholar. A Logick Exercise, London 1659.

- Nobilis virgini Annae Mariae à Schurman, Opuscula Hebraea, Graeca, Latina, Gallica, prosaica et metrica, Ex officina Elzeviriorum, Lugdunum Batavorum 1648. Reprints Leiden 1650, Utrecht 1652, Leipzig 1749.

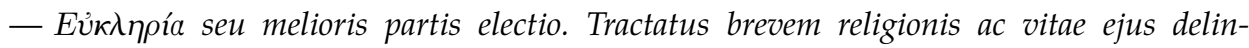
eationem exhibens. Luc. 10:41,42. Unum necessarium. Maria optimam partem ele-

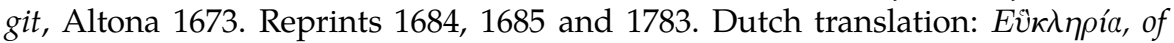
Uitkiezing van het Beste Deel, waar in vertoont wert een kort begrip van haar leven, als mede veel hooftstukken van den godsdienst grondig werden verklaart, Amster-

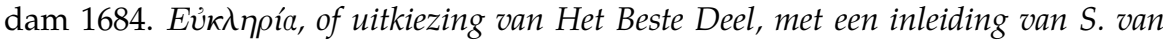
der Linde, De Tille, Leeuwarden 1978 (facsimile).

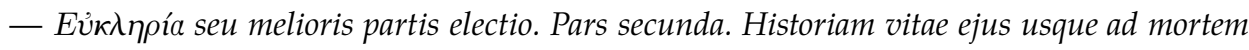
persequens, Amsterdam, 1685. Partial translated in Dutch: Continuatie van de

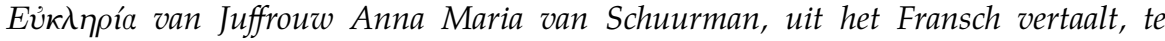
Amsterdam gedrukt in het Jaar 1754. Reprint: Lindenbergs boekhandel, Rotterdam 1974 (facsimile). In this edition is included: Kort verhaal van eenige dingen, raakende de vermaarde perzoon van Juffr. Anna Maria van Schuurman.

- Vraeghbrief, waerom de Heere Christus, daer hy ongeneselijcke Sieckten, soo met een Woordt, so met Aenraken genas, des Blindens oogen met Slick, en Speecksel gestreken heeft?, in: J. van Beverwijck, Wercken der Geneeskonste bestaende in den Schat der gesontheit en ongesontheit. III. Aenhangsel van Brieven, Schipper, Amsterdam 1680, 198-201.

- Mysterium Magnum, Oder: Grosses Geheimnüs, Das ist: Ein sehr herrliches und im heiligen Wort Gottes wohlgegründetes Bedencken Uber die Zukunft des Reichs Christi. Durch die hochgelehrte / in aller Welt beruffene / und von Gott hocherleuchtete Jungfer / Juffr. Anna Maria von Schurmann / Anno 1660 außsgefertigt / nunmehro aber wegen desser Vortrefflichkeit ins Hoch-Teutsche überseßt [...], Andreas Lupius, Wesel/Duißburg/Franckfurt 1699.

- Pensées d'A.M. de Schurman sur la Réformation nécessaire à présent à l'Église de Christ, Jacob van Velsen, Amsterdam 1669. 
- Geleerde brieven van de edele en konst-rijke Juffrouw, Anna Maria van Schurman gewisselt met de geleerde heeren Samuel Rachelius, Professor in de Rechten te Kiel en Johan van Beverwyck, Ned. Doct. tot Dordrecht, Johannes van Septeren, Amsterdam 1728.

- Uitbreiding over de drie eerste capittels van Genesis, beneffens een vertoog van het geestelijk huwelyk van Christus met de gelovigen. Beide in zinryk digtmaat t'zamen gesteld, door wylen Juffer Anna Maria van Schuurman. Nu eerst na het orignele handschrift gedrukt, Jacobus Sipkes, Groningen 1732.

- Zielsverlustiging bestaende in verscheyde geestelycke liederen, 't samen gestelt door eenige godtvruchtige leeraren, en andere. Den tweeden Druck met eenige Gesangen vermeerdert, en van fouten gesuyvert. Coloss. 3 vs 16. Leert en vermaent malkanderen met Psalmen, Lofsangen, en Geestelyke Liederen, zingende den Heere met aengenaemheyt in uwe herten, Johannes Boekholt, Amsterdam 16812.

Signon, Helmut, Klaus Schmidt, Alle Straßen führen durch Köln, Greven Verlag, Köln 2006.

Sneller, A. Agnes, 'Indien zij een man geweest was...'Anna Maria van Schurman in het sociaal-litteraire leven van haar tijd, in: M. de Baar e.a. (ed.), Anna Maria van Schurman (1607-1678), een uitzonderlijk geleerde vrouw, Walburgpers, Zutphen 1992, 139-157.

Spang, Michael, Wenn sie ein Mann wäre. Leben und Werk der Anna Maria van Schurman (1607-1678), Wissenschaftliche Buch Gesellschaft, Darmstadt 2009.

- Dissertatio de ingenii muliebris ad doctrinam et meliores litteras aptitudine. Abhandlung über die Befähigung des Geistes von Frauen für die Gelehrsamkeit und die höheren Wissenschaften. Herausgegeben, eingeleitet, übersetzt und kommentiert von Michael Spang, Köningshausen \& Neumann, Würzburg 2009.

Stighelen, Katlijne van der, Anna Maria van Schurman Schurman (1607-1678) als kalligrafe, in: De Gulden Passer, 64, 1986, 61-82.

- Portretjes in 'Spaens loot' van de hand van Anna Maria van Schurman (1607-1678), in: De zeventiende eeuw, 2, 1986, 27-41.

- Anna Maria van Schurman (1607-1678) of 'Hoe hooge dat een maeght kan in de konsten stijgen', Universitaire Pers, Leuven 1987.

- 'Et ses mains (...)'. De kunstzinnigheid van Anna Maria van Schurman, in: M. de Baar, e.a. (ed.), Anna Maria van Schurman (1607-1678), een uitzonderlijk geleerde vrouw, Walburgpers, Zutphen 1992, 61-74.

Stighelen, Katlijne van der, Jeanine de Landtsheer, Een suer-soete Maeghd voor Constantijn Huygens Anna Maria van Schurman (1607-1678), in: De Zeventiende Eeuw, 25, 2009, 149-202.

Tuinen, Piter van, Twee brieven van Anna Maria van Schurman aan stadsdokter Bernhardus Swalue, 1675. http://www.vergetenharlingers.nl/page/17de-eeuw/\#brieven schurman, 2010.

Usakiewicz, Joanna, Anna Maria van Schurman (1607-1678). Ocellus Niderlandów, in: Studia z Historii filozofii 1, 10, 2019, 171-192.

- Anna Maria van Schurman. Problem praktyczny: Czy chrześcijańskiej kobiecie przystoi zamiłowanie do studiowania nauk?, in: Studia z Historii filozofii 1, 10, 2019, 17-38. 
Verhave, Joke, Jan Peter Verhave, 'Geknipt, gedicht, gekruisigd'. Kunstzinnige activiteiten door of voor Anna Maria van Schurman, in: Jaarboek De Zeventiende Eeuw 2017. Cultuur in de Nederlanden in interdisciplinair perspectief, Verloren, Hilversum 2017, 153-164.

Vekeman, Herman, De nadere Reformatie en de Nederlandse filologie, in: Ons Erfdeel, 25, 1982,706-716.

Verklaringe van de suyverheit des Geloofs en Leere van Jean de Labadie, Pierre Yvon, Piere du Lignon, Herders. Hendrick Schluter, Pieter Schluter, Predikers. Als oock mede van veele andere geloovigen, die God met malkanderen vereenigt heeft, om waare Kerken te maken, Gereformeert soo wel in Leere, als in Leven, Bestier, ende Leydinge. Gevoeght by de vernieuwde Protestatie, rakende het gesonde Geloove, en de algemeine Regtsinnightyt van Jean de Labadie, Herder. Uyt het Frans vertaelt, door haer selfs, den tweeden druk, nu merkelyk vermeerdert, Laurens Autein, Drucker van de France en Nederduytse Kerke, op de Vorstelyke Vryheyt tot Herfordt 1671.

Veth, Johanna, Anna Maria van Schurman (1607-1678), in: Onze Eeuw, 22, 1922, 219 241.

Visser, Hugo Bastiaan, De geschiedenis van den sabbatsstrijd onder de gereformeerden in de zeventiende eeuw, Kemink en Zoon, Utrecht 1939.

Visscher, Hugo, Guilielmus Amesius, zijn leven en werken, J.M. Stap, Haarlem 1894.

Visscher Hugo, L.A. van Langeraad, Biographisch woordenboek van protestantsche godgeleerden in Nederland. Deel 1, Kemink \& Zoon, Utrecht 1907.

Voetius, G., Dissertatio Epistolica de Termino Vitae ad Ampliss. Clarissimumque Johannem Beverovicium [...], Editio altera, Esdras Wilhelmus, Utrecht 1641.

Witteveen, K.M., Anna Maria van Schurman, in: Biografisch lexicon voor de geschiedenis van het Nederlandse protestantisme, Deel II, Kok, Kampen 1983, 396-399.

\section{Summary}

My article investigates Van Schurman's spirituality and scientific activities by studying her biography in which both elements are present. What is her balance between faith and science? Both are continuing characteristics of her life. The title of my article: Credo ergo cogito shows my position on this question. It is often said that she was quite a different person after joining the Labadist movement. In my view there is more continuity than discontinuity ${ }^{207}$. Her faith always takes the first place, although intellectual thinking is very important. The saying of Augustine: Fides quaerit intellectum fits well into her way of life. It is not accidental that she seeks companionship with the learned world of her time and especially with

207 Larsen comes to the same conclusion: "Although her critics thought her decision completely unjustified, her move should not surprise as it was consistent with her earlier choices", Larsen 2018, 305. 
Voetius, who also sought the connections between piety and science: Pietas cum scientia coniugenda. By investigating her life I discovered an ongoing continuity. In her childhood faith and intellectual education were both important. As young woman she developed her artistic talents in order to praise the Creator and she pursued her linguistic skills, on order to know the Bible better. Her faith came before science, not the other way around.

\section{Anna Maria van Schurman (1607-1678). Uczona i jej dążenia ku prawdziwej duchowości}

\section{Streszczenie}

Artykuł bada duchowość i działalność naukową van Schurman poprzez pryzmat jej biografii, w której znajdziemy oba te elementy. W jaki sposób uczona godziła ze sobą wiarę i naukę? Obie te sfery były nierozłącznymi elementami jej życia. Tytuł artykułu: Credo ergo cogito wskazuje na moją opinię w tej kwestii. Często wspominany jest fakt, jakoby osobowość uczonej uległa drastycznej zmianie po wstąpieniu do sekty Labadystów. Jednak w moim przekonaniu możemy zauważyć więcej cech wskazujących na trwałość w poglądach, niż na fundamentalną zmianę (Larsen podziela ten pogląd). Wiara zawsze była dla uczonej najważniejsza, choć myśl naukowa również zajmowała znaczące miejsce. Sentencja powtarzana przez Augustyna z Hippony: Fides quaerit intellectum dobrze wpasowuje się $\mathrm{w}$ jej życie. Nie przypadkiem starała się budować znajomości w sferze uczonych jej czasów, szczególnie z Voetiusem, który również szukał związków między pobożnością a nauką: Pietas cum scientia coniugenda. Poprzez analizę jej życia, dostrzegłam niezmienne cechy jej osobowości. Już w dzieciństwie, wiara i edukacja naukowa miały kluczowe znaczenie. Jako młoda kobieta, rozwijała swoje umiejętności artystyczne, aby lepiej czcić Stwórcę, jak i językowe, aby głębiej poznać Biblię. Ostatecznie, dla van Schurman wiara zawsze była ważniejsza od nauki.

Rev. Dr. Margriet Gosker is an ordained minister of the Reformed Church in the Netherlands and an independent Scholar. She got her PHD in Budapest. She publishes about Church History and Ecumenical Issues. In 2014 she got the Royal Honour of Officier in de Orde van Oranje Nassau. The Dutch Protestant Theological University put her in 2020 on the list of female heros of Dutch Church History as number nine, because of ecumenical work, her ongoing struggle for women's ordination and for her voluntary work as Leader of the Luther year in the Netherlands in 2017. She is a member of Faith and Order in the Netherlands, she was a member of the Joint Working Group in order to institute the WCRC and she was a member of the Doctrinal Study Group on Ministry, Ordination and Episkope of the CPCE.

e-mail: dr.m.gosker.venlo@hetnet.nl http://www.margrietgosker.com 